\title{
Review on the mesenchymal stem cells and their potential application in regenerative medicine
}

\author{
M. Nassiri Asl ${ }^{1,2}$, E. Aali $^{2}$
}

\footnotetext{
${ }^{1}$ Cellular and Molecular Research Center, Qazvin University of Medical Sciences, Qazvin, Iran

${ }^{2}$ Department of Pharmacology, School of Medicine, Qazvin University of Medical Sciences, Qazvin, Iran
}

Corresponding Address: Ehsan Aali, Department of Pharmacology, School of Medicine, Qazvin University of Medical Sciences, Qazvin, Iran

Tel: +98-28-33336001, Email: E.aali@ qums.ac.ir

Received: 23 Sep 2017; Accepted: 16 Oct 2017

\section{Abstract}

Stem cells are unspecialized cells that are capable of self-renewal and differentiate into a variety of cell types. Indeed, stem cells are able to differentiate into functional specialized cells e.g. myocardiocyte, neurocyte, osteoblast, adipocyte, chondrocyte, etc. Among stem cells, mesenchymal stem cells (MSCs) have been considered by researchers on account of having differentiation ability into variety of cells with no risk of tumorogenicity and immune system stimulation. The aim of this article is reviewing of stem cell types, their sources, MSCs, their features and characteristics, their potential in regenerative medicine and their clinical application in medicine. Information have been gathered in the present review study in 2017, by referring to the following databases; PubMed, Science Direct, Ovid Databases, Scopus, Wiley and Springer. MSCs have an ability to differentiate into various cells e.g. osteoblast, adipocyte, myocardiocyte, chondrocyte, myoblast, neurocyte, neuroglia cells, myocyte, endothelial cells, isle cells, etc. Also, it seems that MSCs have been preferred in regenerative medicine because of having immunomodulatory properties and ability of secretion of various cytokines and growth factors. Development of human knowledge in the field of producing, proliferation and differentiation of stem cells, bring the hope of using these cells in treatment of neural lesion e.g. spinal cord injury, multiple sclerosis, Alzheimer, parkinsonism, etc.

Keywords: Stem cell, Mesenchymal stem cell, Regenerative medicine

Citation: Nassiri Asl M, Aali E. Review on the mesenchymal stem cells and their potential application in regenerative medicine. J Qazvin Univ Med Sci 2018; 21 (6): 74-89. 
مرورى بر سلولهاى بنيادى مزانشيمى و كاربرد بالقوه آنها در طب بازساختى

دكتر مرجان نصيرى اصل او'، دكتر احسان عالى؟

' مركز تحقيقات سلولى و مولكولى دانشكاه علوم يزشكى قزوين، ايران

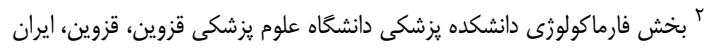

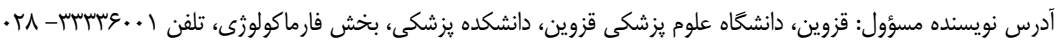

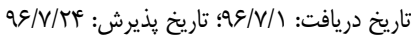

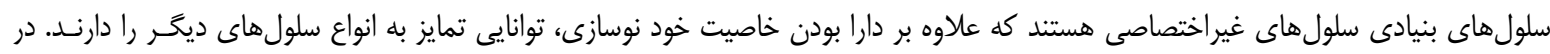

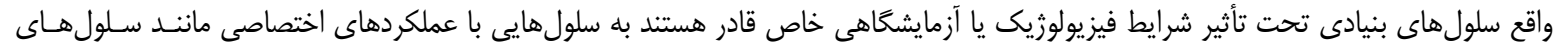

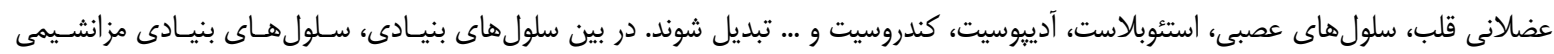

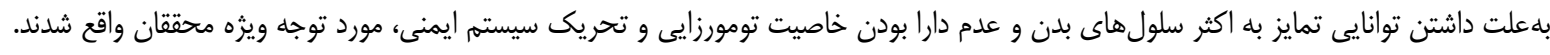

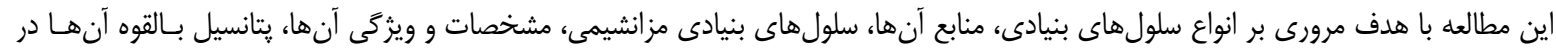

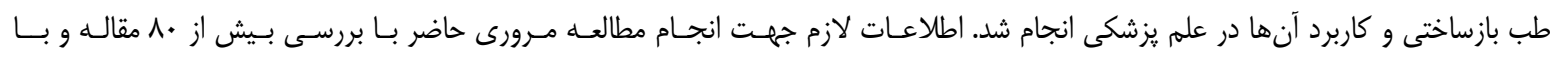

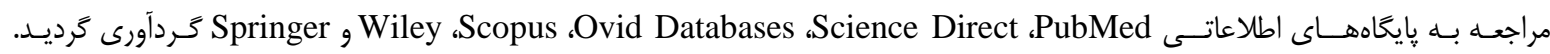

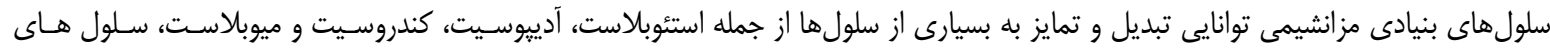

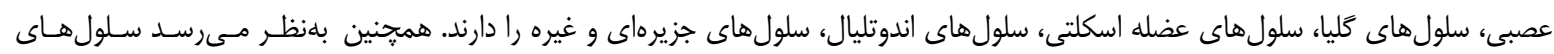

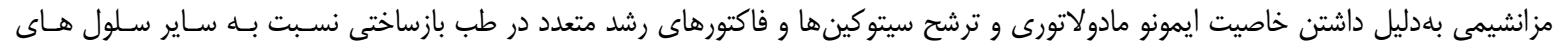

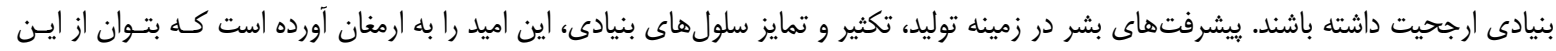

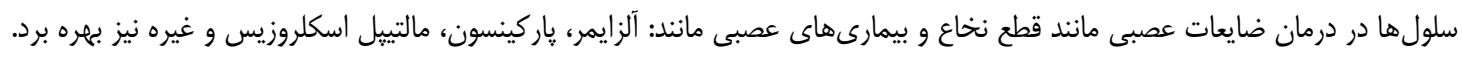

كليدوازهها: سلول هاى بنيادى، سلول هاى بنيادى مزانشيمى، طب بازساختى

مقدمه:

صورت گرفته است. لغت Stem از اصطلاحات گياهشناسى

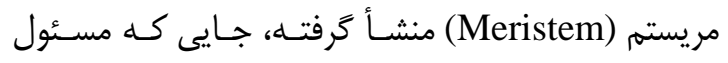

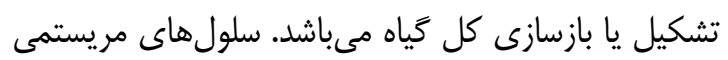

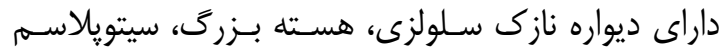

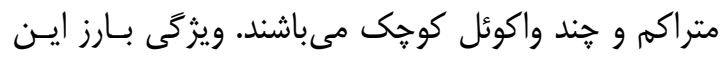
سلولها قدرت تمايز و تكثير بالاى آنهاست. (َ)

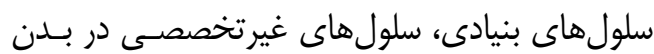

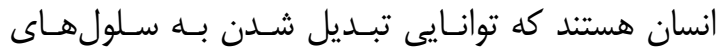

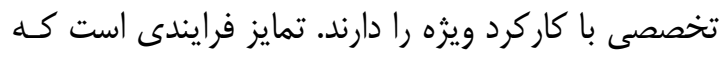
در آن سلولهاى غيرتخصصى با بـهدســــ آوردن صـفات خاص سلولى به سلولهاى تخصصى تبديل مى شوند. اين

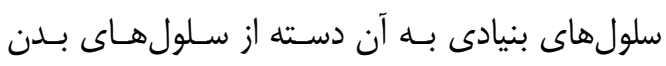

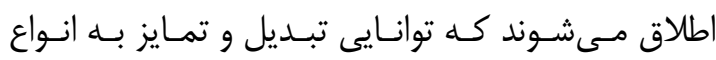

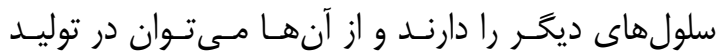
سلولها و در نهايت بافتهاى مختلف ديخر استفاده كـرد.

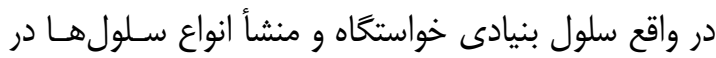

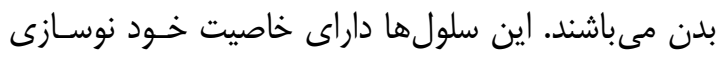

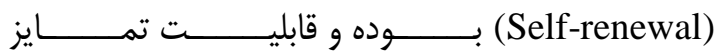

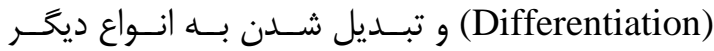

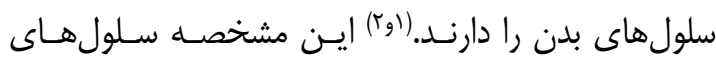

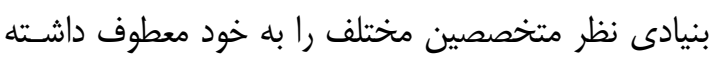

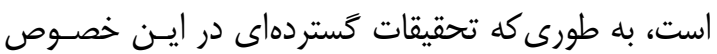


Potrnt = توانا) عملكرد مهمـى در نخــهدارى بافـتهـا در

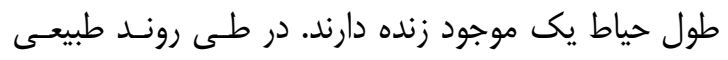

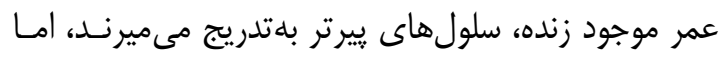

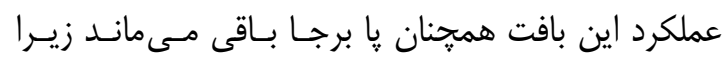

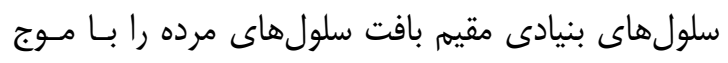
جديدى از سلولهاى تخصصى شده جايكزين مسىنماينـد.

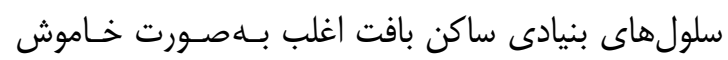

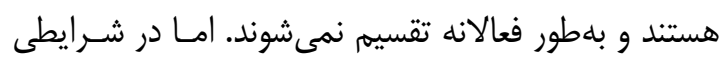

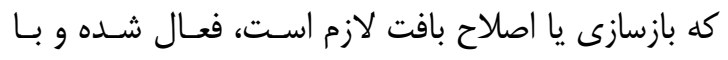
تكثير و تمايز به سلولهاى تخصصى عملكرد بافت مـورد نظر را تأمين مى كنند. (v) تمايز به سلو

\section{مواد و روشها:}

در مطالعه مرورى حاضر با اسـتفاده از كليـدوازههــاى مولى

،Mesenchymal Stem Cell stem Cell Tissue Regeneration gegenerative Medicine در پايخاههـاى اطلاعاتى Science Direct، PubMed، Springer و Wiley ،Scopus ،Ovid Databases

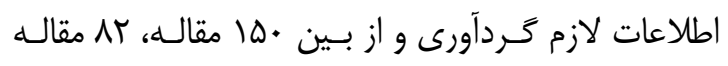
مرتبط با موضوع انتخاب شدند.

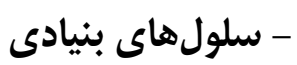
1 - دستهبندى سلولهاى بنيادى برى براساس قدرت تمايز قدرت تمايز (Potency) به يتانسيل و توانـايى تمـايز

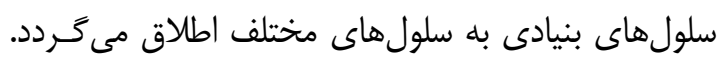
بلهور كلى سلولهاى بنيادى داراى دو خصوصيت عمــده

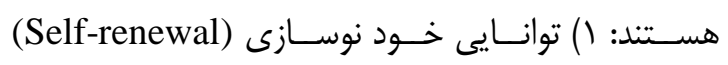
r) خصوصيت يرتوانى (Unlimited potency). بلهعبارت

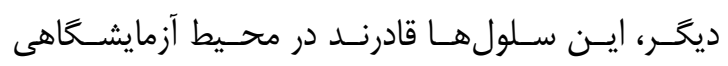

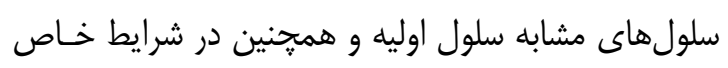

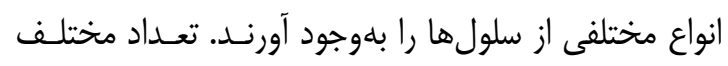
سلولهاى تخصصى كه يك سلول بنيادى مسى توانـــ بــهـ

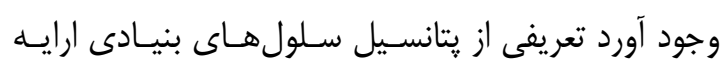

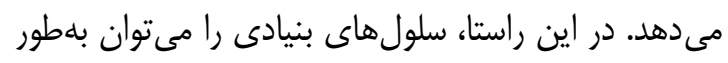

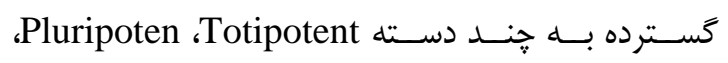

فرايند يك ويثزى كليدى سلولهاى بنيادى اسـت. بـراى مثال، سلولهاى بنيادى خون بهاين دليل بنيادى محسوب سلئي

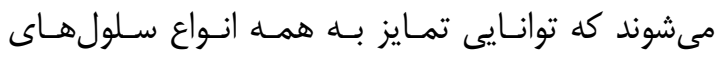

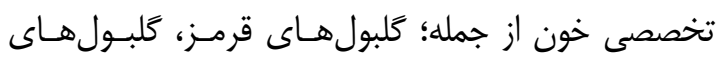

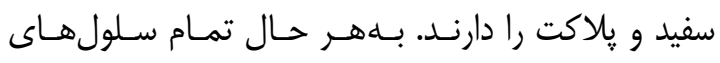
تخصصى سيستم خون از جمعيت سلولهاى بنيادى خون

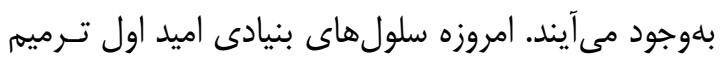

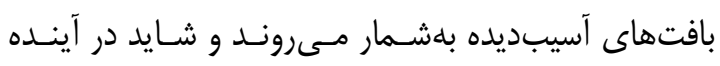

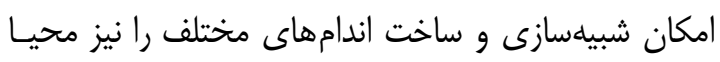

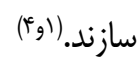

تلاش براى استفاده از سلولهـاى بنيـادى جنينـى از

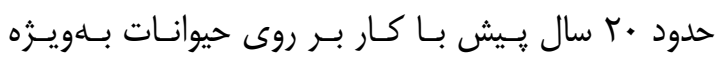

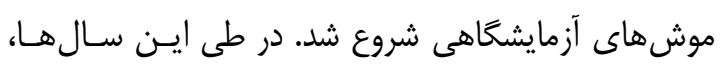

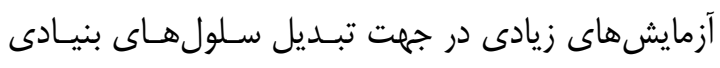

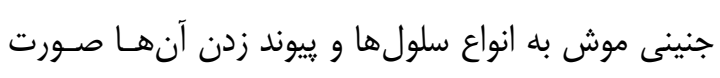

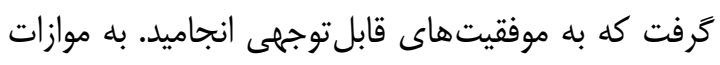
تحقيقات حيوانى، سلولهاى بنيادى انسان نيز مورد توجـهـ

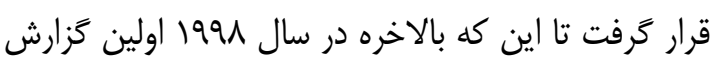

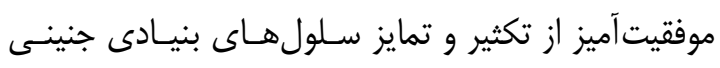

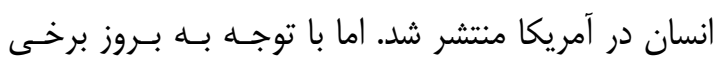

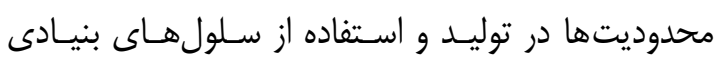
جنينى (كه تلاش براى رفع آنها ادامه دارد) در جند سال

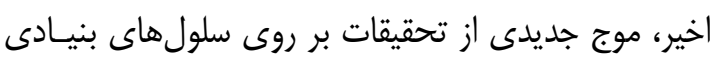

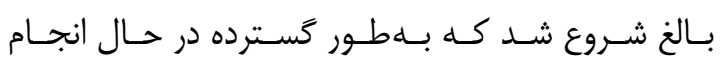

$$
\text { مىباشد." مالغ شتروع }
$$

در سال 1991 دانشمندان بـراى اولـين بـار توانسـتند

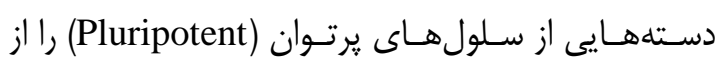

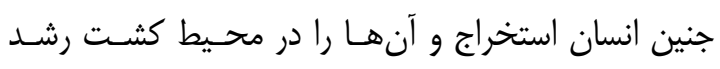

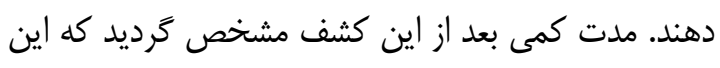

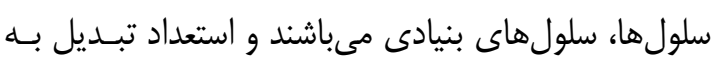
انواع مختلفى از سلولهاى بدن رأ دارئ دارا مى باشند. بنـابراين

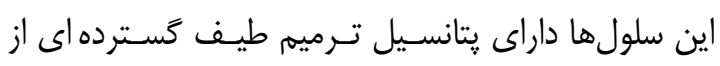
بافتهاى بدن شامل قلب، عضله و... مىباشند. (هو و)

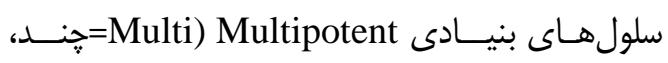


يوست و عضله حضـور دارنــــ ايـن جمعيـت سـلولهـاى بنيادى در بافتهاى ميزبان براى حيات يك موجود زنسده

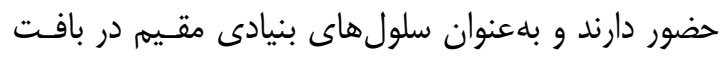

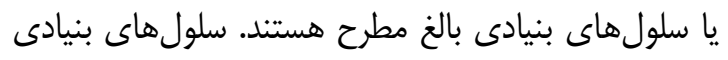

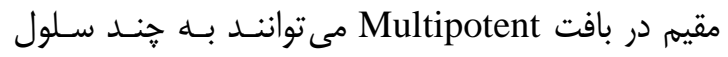
تخصصى از يك خانواده در يك موجود زنسـده تمـايز ييـدا كنند. سلولهاى بنيادى بالغ (Hematopoietic Stem Cell)

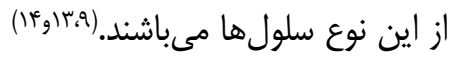

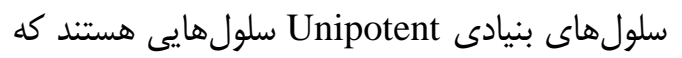

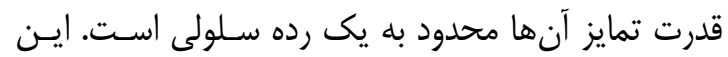

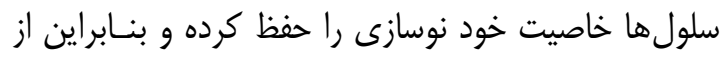

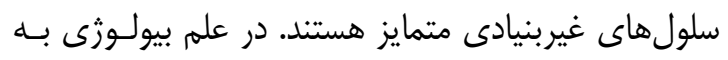
اين نوع، سلولهاى بيشساز هم كفته مىشود. براى مثال

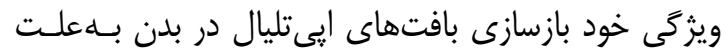

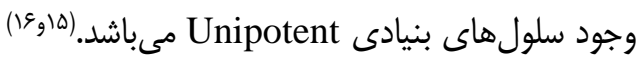
r- دستدبندى سلولهاى بنيادى براساس منبع آنها تاكنون انواع مختلفى از سلولهاى بنيادى از جنسين

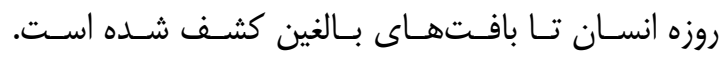

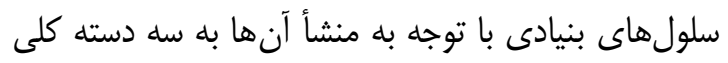

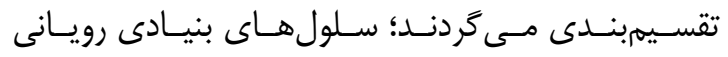
(Embryonic Stem Cells) (Fetal Stem Cells) ( $\vee_{9} 9$ ).(Adult Stem Cells)

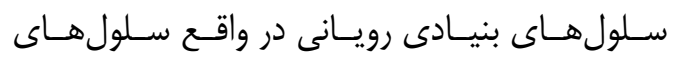

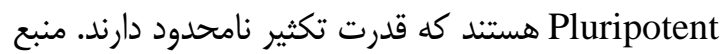
اين سلولها از رويان در حال رشد مىباشد. در واقع تـوده

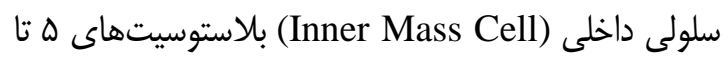
צروزه انسانى منبع سلولهاى بنيادى رويانى مى باشند. در طول تكامل رويان، توده سلولى داخلى به دو لايه مجزا به

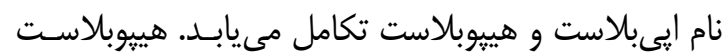

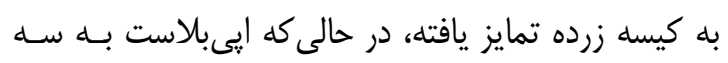

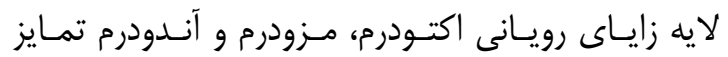

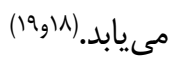
سلول هاى بنيادى بالغ يك سرى سلولهاى غيرتمايز
Multipotent واقع سلولهاى بنيادى Totipotent، زيخوت و سلولهاى

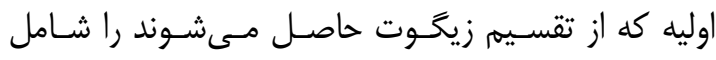

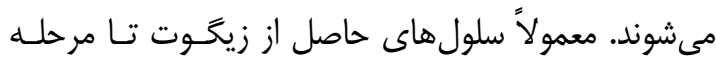

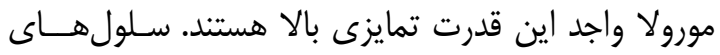

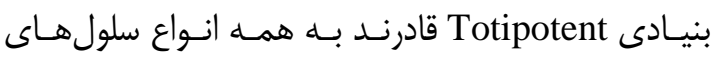

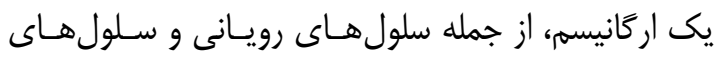
خارج رويانى (شامل بافتهاى حمايتى جنين، مانند جفـت إنى

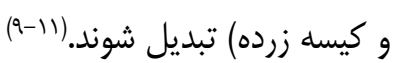
سلولهاى بنيادى Pluripotent قدرت تمايز به تقريباً

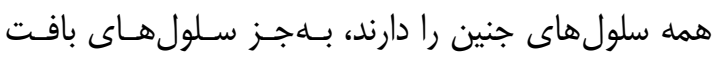

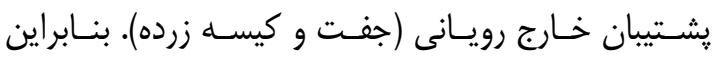

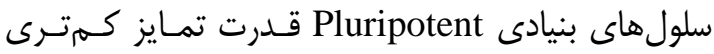
نسبت به سلولهـاى بنيـادى Totipotent دارنسـ و قـادر نيستند به يك موجود زنده كامل تكامل يابند. هنخامى كه به

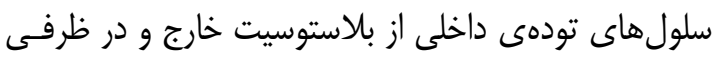

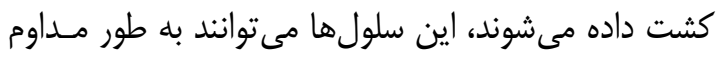

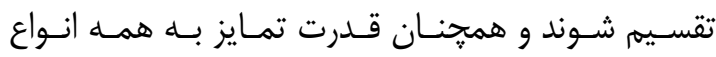

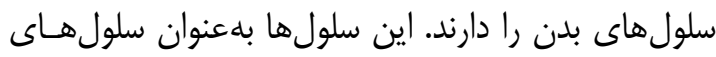
بنيـادى رويـانى (Embryonic Stem Cells) شـناخته مى شوند. در رويان، سلولهاى توده داخلى بله سه لايه زايا

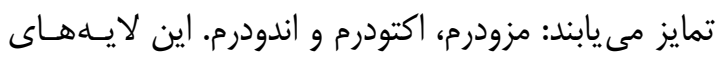

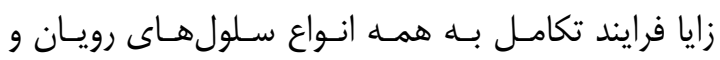

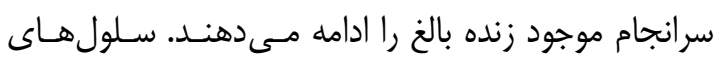
بنيادى Pluripotent بهطور قابل ملاحظهاى مى توانند در

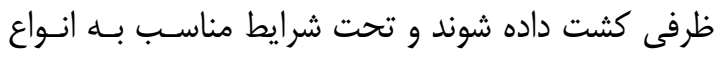
مختلف سلولهاى تخصصى يكى موجود زنده تمايز يابنــــ

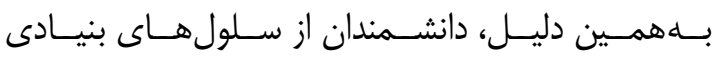

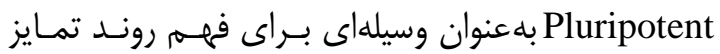

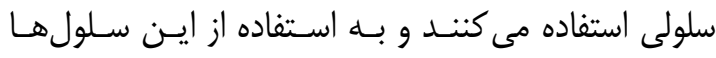

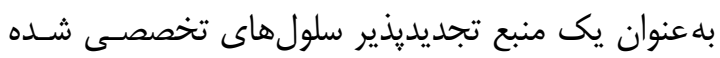

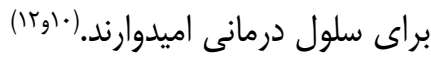
سلولهاى بنيادى Multipotent يا سلولهاى مقيمي ديد بافت در بافت هاى مختلف بدن مانند مغز استخوان، مغـز، 
بافتهاى جنين يافت مىشوند. اين سلولها را مىتوان از

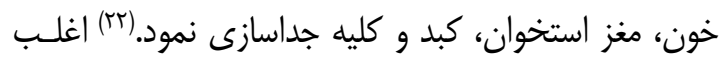

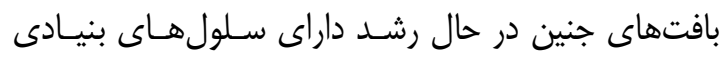

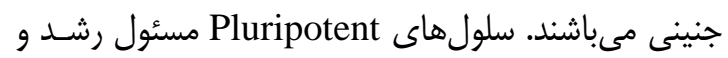
تكامل سريع بافتهاى جنين مىباشند. خون جنين حاوى

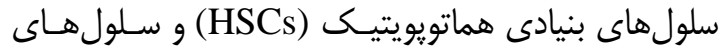

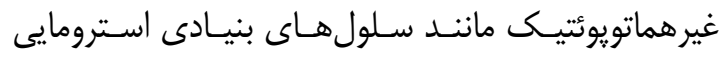

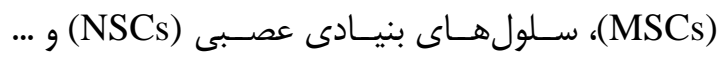
مىباشد كه قابليت تكثير و تمايز به انواع سلولهاى مورد

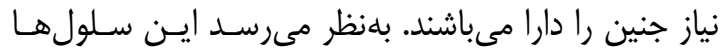

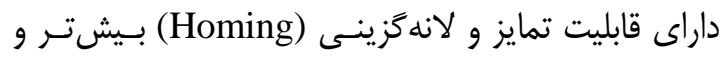

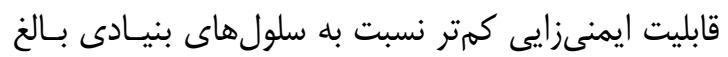

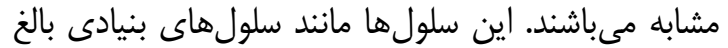

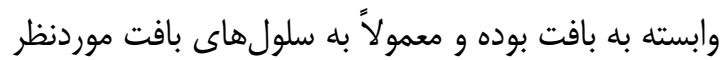

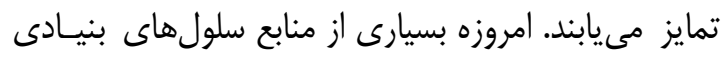

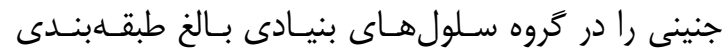

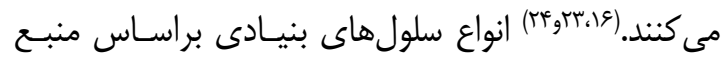
آنها و همجنين مزايا و محدوديتهاى هر كدام در جدول ا خلاصه شده است.
يافته مىباشند كه در داخل بافتها و انــامهـاى مختلـف

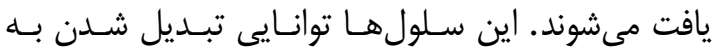

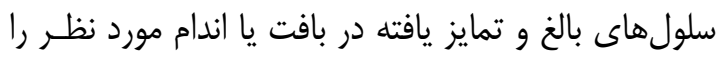

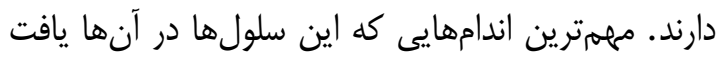

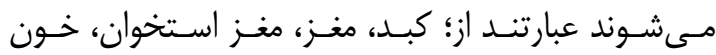

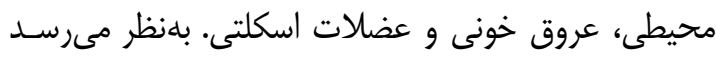

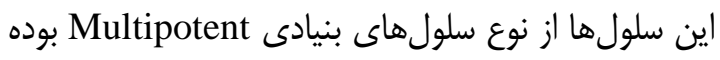

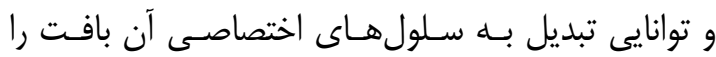
داشته باشند. نقش اصلى اين سـلولهـانـا احتمـالاً تـرميم و

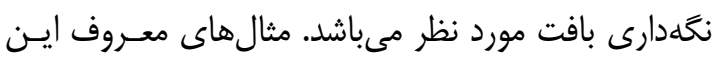

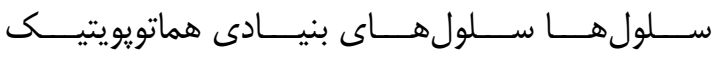
(Bone Marrow Hematopoietic Stem)

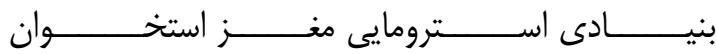
(Bone Marrow Stromal Stem Cells)

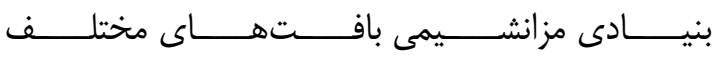
(Mesenchymal Stem Cells) بافت جربى (Adipose Derived Adult Stem Cells)

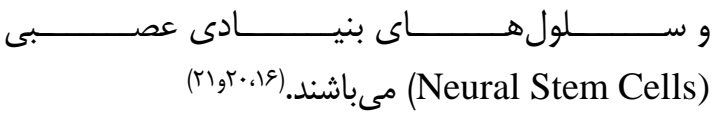

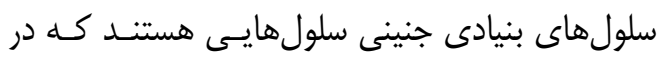

جدول ا - انواع سلولهاى بنيادى براساس منبع آنها، مزايا و محدوديتهاى آنها

\begin{tabular}{|c|c|c|c|c|}
\hline منابع & محدوديتها & مزايا & نوع سلول بنيادى & \\
\hline$(r \Delta-r \Lambda, \mid q)$ & عدم جداسازى آسان (ملاحظات اخلاقى) & قدرت تمايز بالا (Pluripotent) قدثير بالا & رويانى & 1 \\
\hline$\left(r Y-r^{\prime}, g\right)$ & قدرت تمايز محدود & قدرت لانهز قدينى بالا & جنينى & r \\
\hline$(r 9, r \Lambda, r) .19)$ & قعداد محدود دمر بافتها محدود & حداقل تحريك سيستم ايمنى حداقل خداصيت تومورزايى & 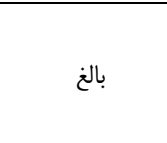 & r \\
\hline
\end{tabular}


نمى آيد. شايان ذكر است، يسزدمى، يكى از محدوديتهاى

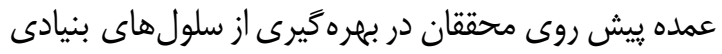

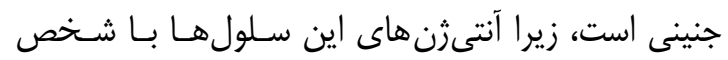

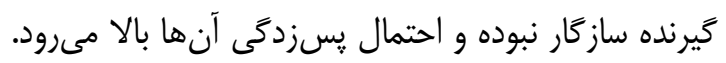

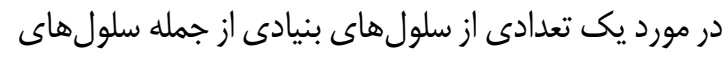

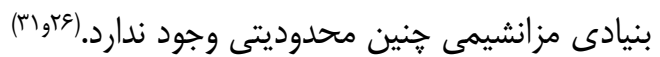

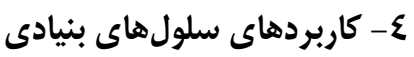

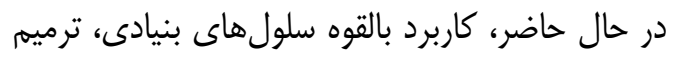

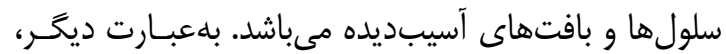

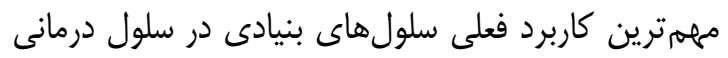
مىباشد و اميد است كه در آينده نزديك سلول درمانى (Cell Therapy)

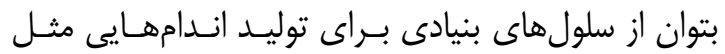

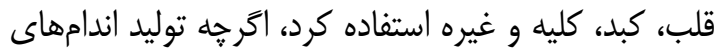

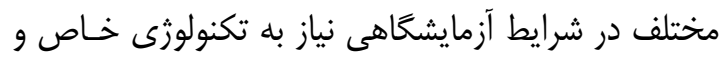

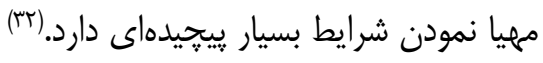
هر קند استفاده از سلولهاى بنيادى در مراحـل اوليـهـ خود بهسر مى برد، اما متخصصان معتقدند در آينـدهاى نـهـ

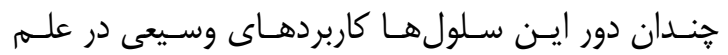

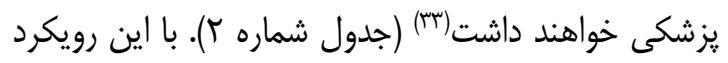

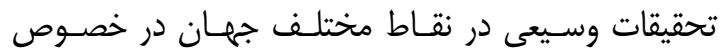
استفاده از سلول هاى بنيادى براى بهبــود سـامت انسان

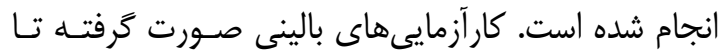

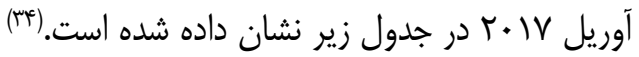

\section{جدول ؟ - كار آزمايىهاى بالينى صورت تَرفته در سراسر دنيا به تفكيك هر منطقه}

\begin{tabular}{|c|c|}
\hline تعداد كارأزمايى بالينى انجام شده & نام منطقه \\
\hline f. & أفريقا \\
\hline iv & أمريكاى مركزى \\
\hline TVQ & كانادا \\
\hline 19 & آمريكاى جنوبى \\
\hline ru.r & ايالت متحده \\
\hline re & مكزيك \\
\hline שו & ارويا ت كيا \\
\hline FT & زإين \\
\hline 1) & أسياى شمالى \\
\hline 9. & أسياى جنوبى \\
\hline TQV & خاورميانه \\
\hline s49 & آسياى شرقى \\
\hline$\overline{v r}$ & آسياى جنوب شرقى \\
\hline$|M|$ & استراليا \\
\hline 0991 & كل دنيا \\
\hline
\end{tabular}

ب- ويزَّى هاى سلولهاى بنيادى

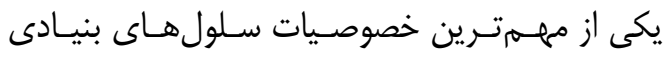

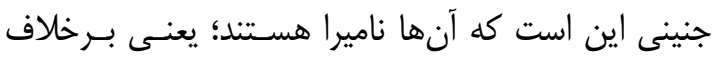

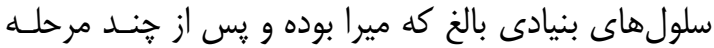
كشت و تكثير، دهار فرايند بيرى مسى شـوند، سـلولهـاى

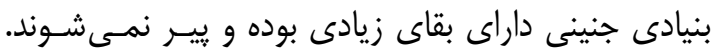

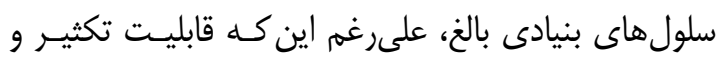

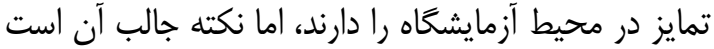

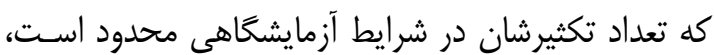

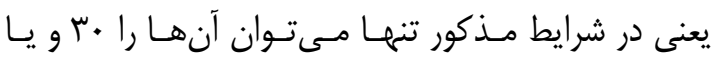

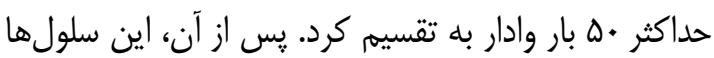

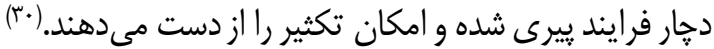
سلولهاى بنيادى داراى قدرت تكثير و تمـايز بـالايى فيى

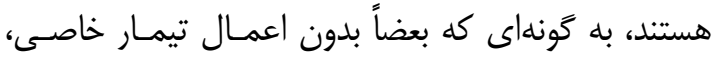

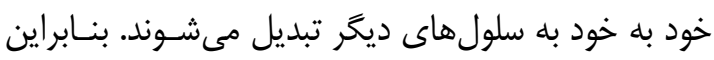
بايد جلوى تمايز ناخواسته و تصادفى آنها كَرفته شـود تـا تبديل به بافتهاى ديخر نشوند. سلولهاى بنيـادى بـالغ تالغ

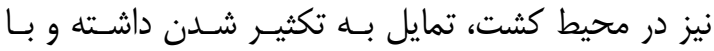

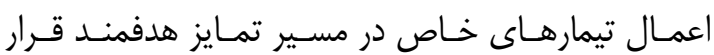
مى گيرند. در صورتى كه مسير تكثير و تمايز اين سلولهـا

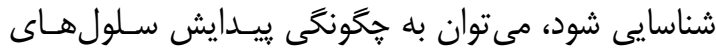

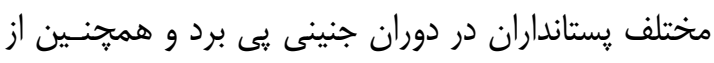

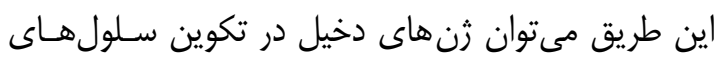
مختلف (نظير قلب، اعصـاب و غيـره) را شناسـايى نمـود. سلولهاى بنيادى هم بلهـورت برونتــى (in vitro) و هم بلهصورت درونتنى (in vivo) قابليت تمايز و تبديـل بلديل به همه سلولهاى بلدن را دارند. محققان در تلاش هستئن با شناسايى مسيرهاى اصلى تمايز اين سلولها، بافتهـاو سلول هاى مختلف را ترميم نمايند..vاو.r)

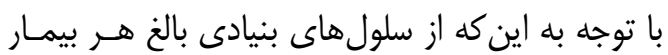

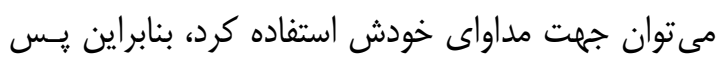

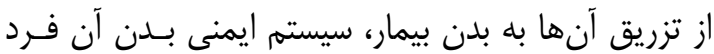

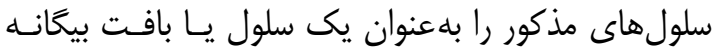

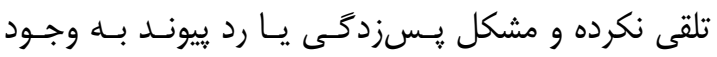




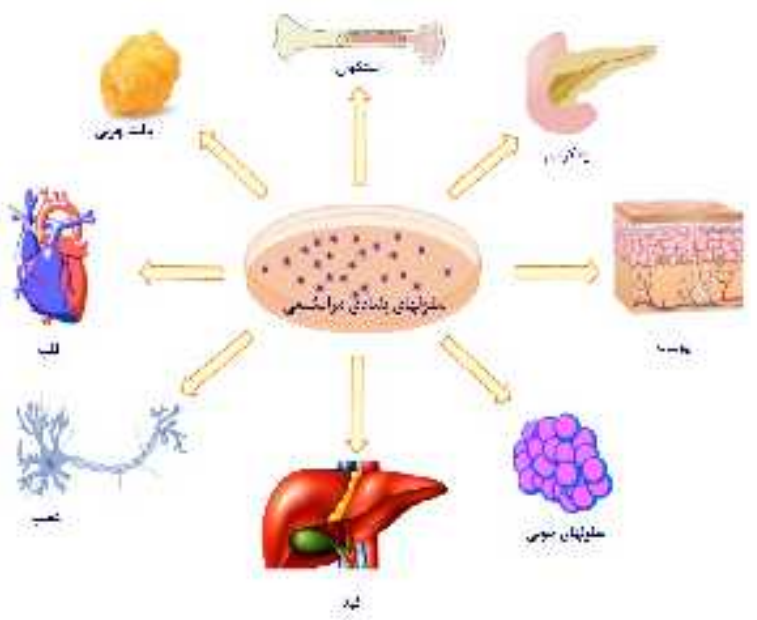

شكل ا - يتانسيل تكثير و تمايز سلولهاى بنيادى

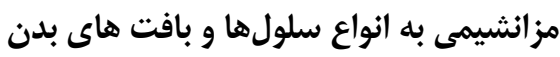

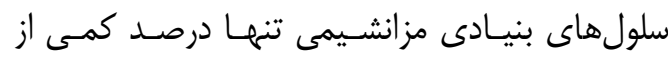
جمعيت سلولهاى مغز استخوان هستند. بيشترين ميزان

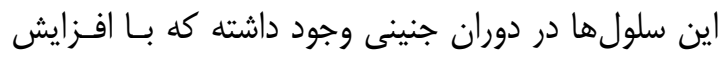

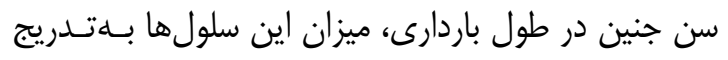

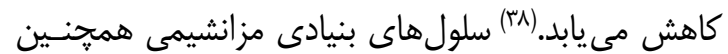

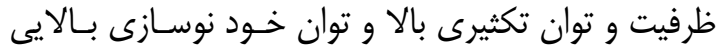

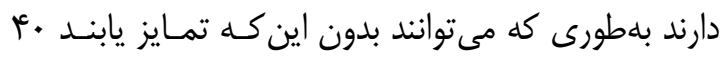

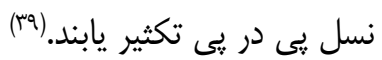

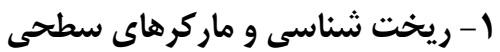

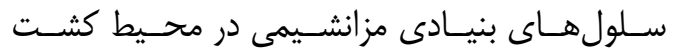

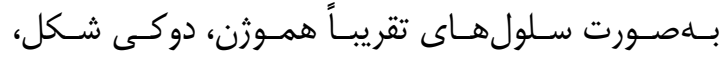

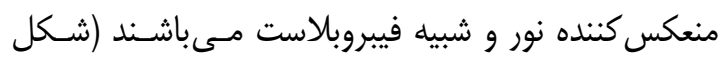

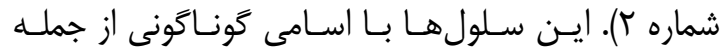
سلولهاى بنيادى شبه فيبروبلاست و سلولهـاى بنيـادى

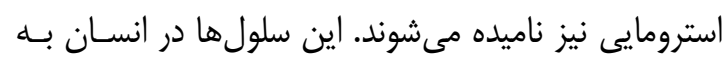

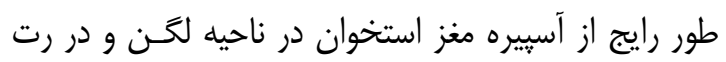

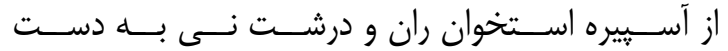

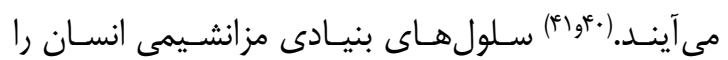

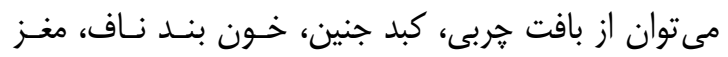

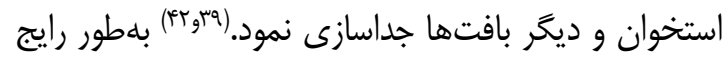
اين سلولها به همراه ساير سلولهاى تكى هستهاى مغـز
در تحقيقات مختلـف سـلولهـاى بنيـادى را از مغـز

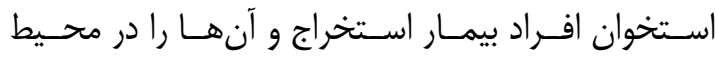

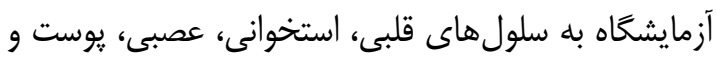

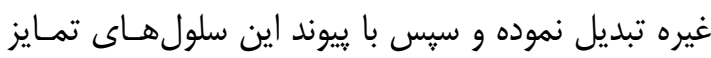
يافته به بدن، درصدد ترميه بافتهاى آسيبديده بيمـاران

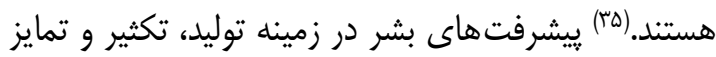

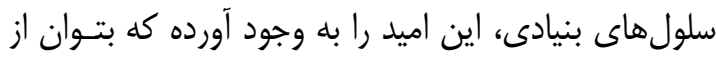

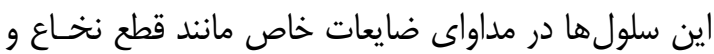
بيمارى هاى عصبى همجِون؛ آلزايمر، يار كينسون، مالتيبـل

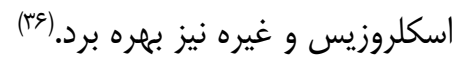

- سلولهاى بنيادى مزانشيمى (MSCs)

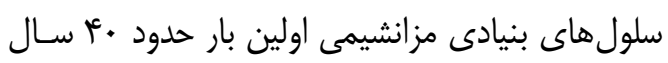

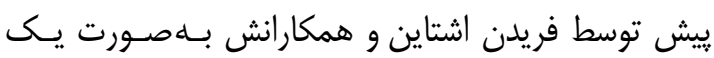

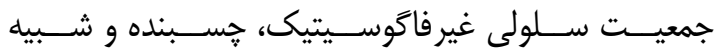

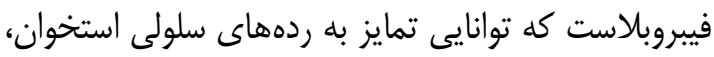

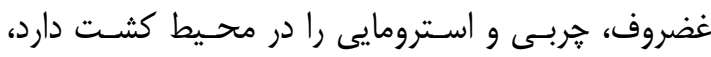

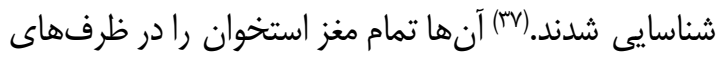
كشت קِلاستيكى ريختند و پِ از آب ساعت سلولهـايى

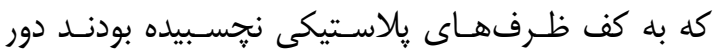

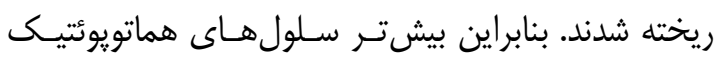

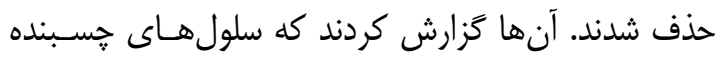

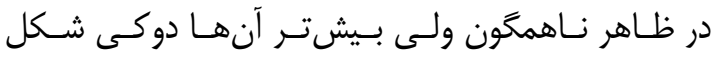

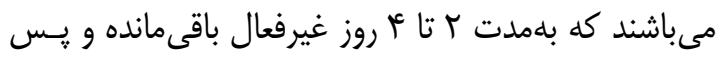

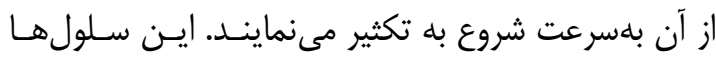

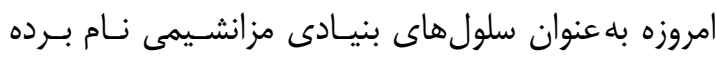

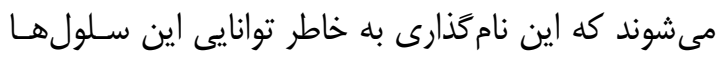

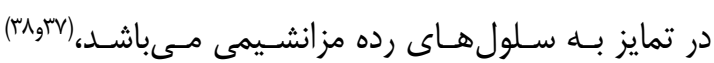

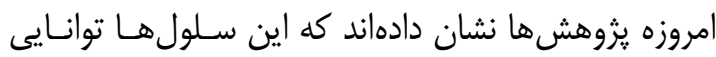

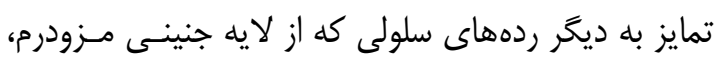
مشتق نشدهاند را نيز دارند كه بـهـعــوان تمـايز بينـابينى شناخته مىشود (شكل شماره (). 


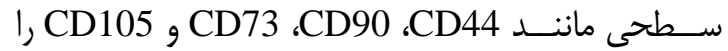

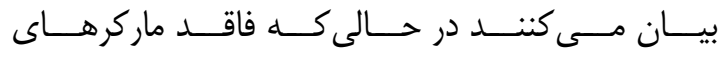
CD45 CD31، CD34 مىباشند. CD

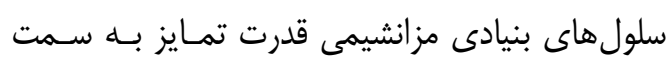

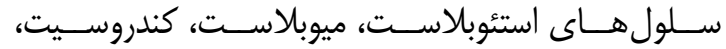

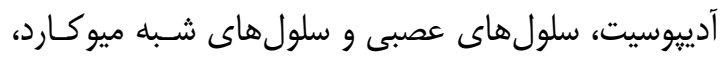

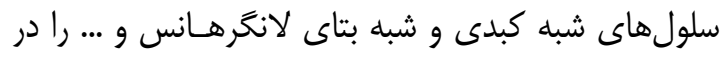

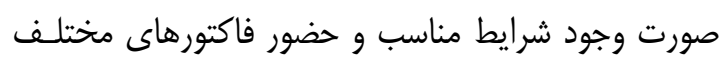

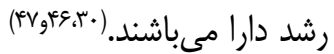

\section{r- ويزَّى مهاجرتى و لانه تزينى (Homing)}

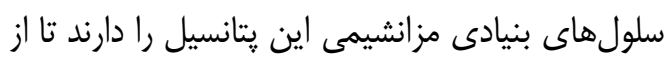
محلهاى مختلف جدا شده و در كردش خئ خون حضور يابند و خود را به محلهاى آسيبديده رسانده و باعـث تـرميم

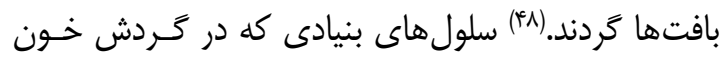

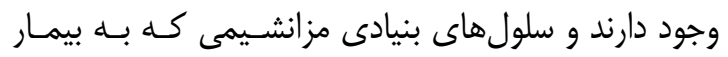

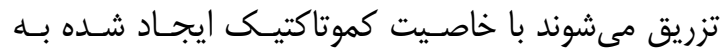
محل ضايعه ممهاجرت مى كنند. در واقع קديده لانه گزينسى يديدهاى است كه سلولهاى ايمنى در هنعام التهـاب بــهـ

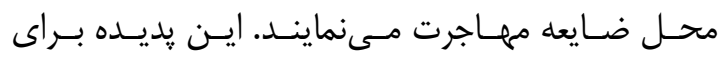

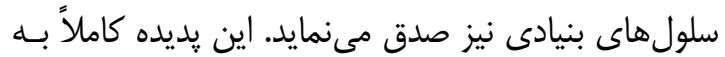
وجود رسيتورهاى موجـود در سـطح سـلولهـاى بنيـادى

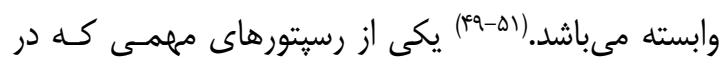

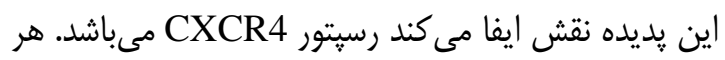

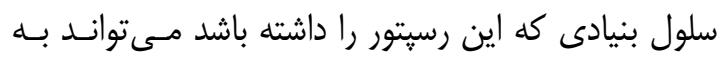
محل ضايعه مهاجرت كند. سلولهـاى مزانشـيمى بـا دارا

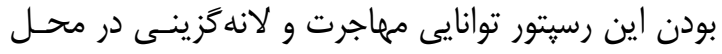

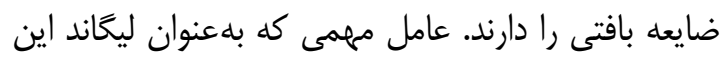

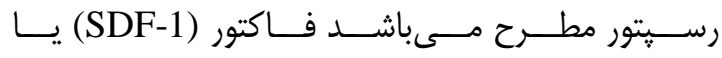
(Stromal Derived Factor-1) محل ضايعه بافتى تشكيل شده و سلولهاى بنيادى را بـهـ

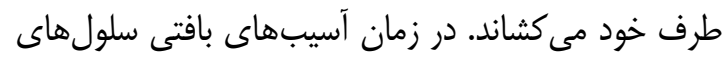
بنيادى از مغز استخوان به سمت كردش خون محيطى و سيّ به محل ضايعل، توسـط فراينــد كموتاكسى ايجـاد

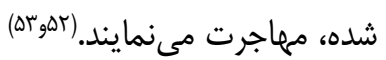

استخوان از آسييراسيون مغز استخوان جداسازى مى گردد.

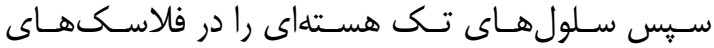
״لاستيكى حاوى محيط كشتهاى اختصاصى سلولهـاى

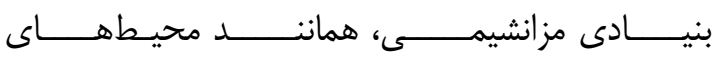
و (Dulbeccos Modified Eagles Medium) DMEM Minimum Essential Medium) Alpha MEM L غنى شده با سرم جنين (Eagle-Alpha Modification كاوى (Fetal Bovine Serum: FBS) كشت مى دهند.

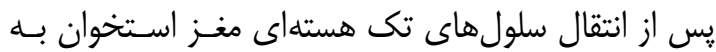

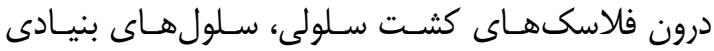

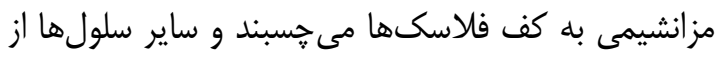
جمله سلولهاى هماتويويتيك، شناور باقى مى مانند كه در هنخام تعويض محيط كشت و پاساز سلولى دور ريخته مى شوند. تكثير بیى در بى سلولهاى بنيادى مزانشيمى تمـام

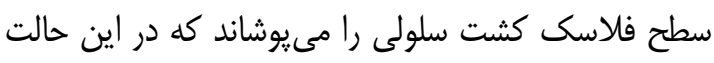
مى توان سلولهاى بنيادى مزانشيمى را بلوسيله تريسيسين

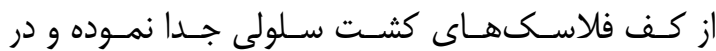
فلاسكهاى جداگانه پاساز داد.(F)

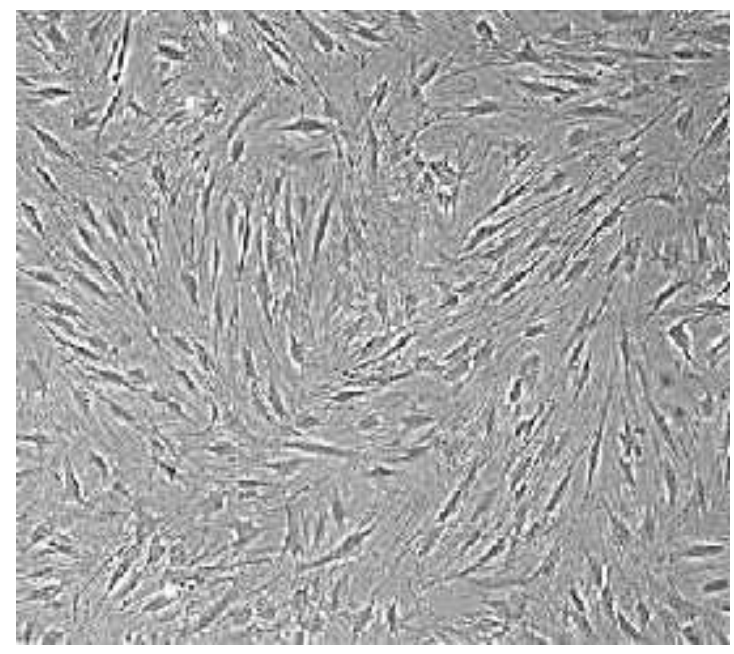

شكل r ب - سلولهاى بنيادى مزانشيمى، سلولهاى دوكى شكل،

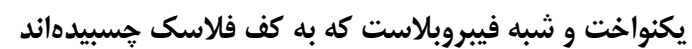

ماركرهاى مختلفى براى شناسايى سلولهاى مزانشيمى وجود دارد. سلولهاى بنيادى مزانشيمى يكسرى برى آنتىثن سنائن 
درمانى تبديل مسى كنـــ. سـلولهــاى بنيـادى مزانشـيمى

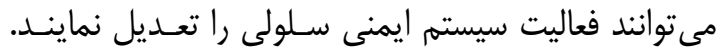

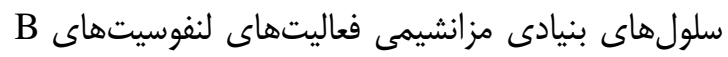

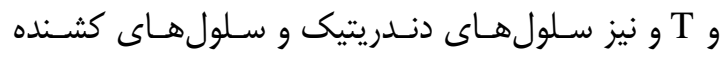
طبيعى (NK) را كاهش مى دهند. مهمترين تأثير آنها اثر كان

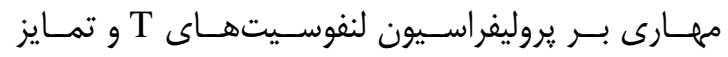

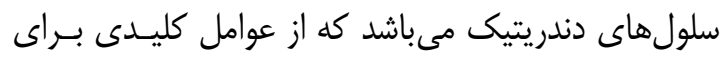

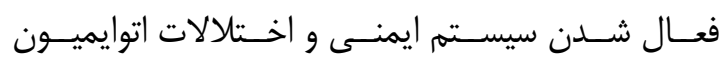

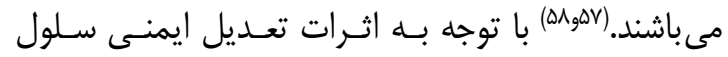

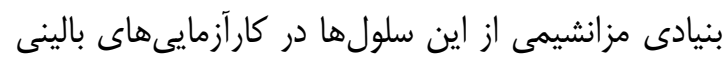

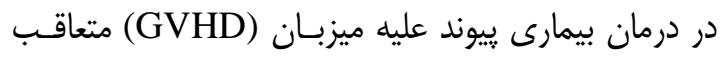

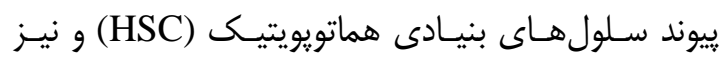

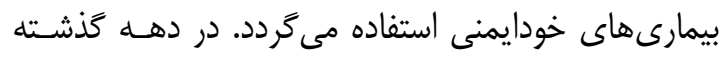
نقش سلول هاى بنيادى مزانشيمى در درمان بيمارى بييوند

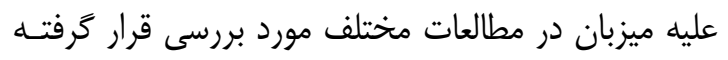

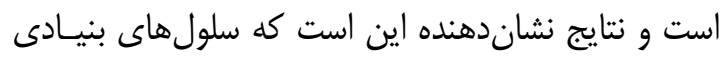

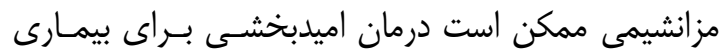

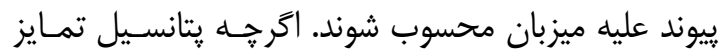
بالاى سلولهاى بنيادى رويانى (ESCs) به وضوح فراتر

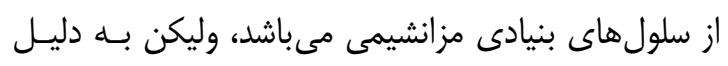

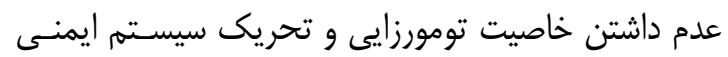

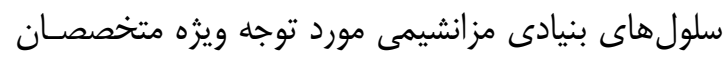

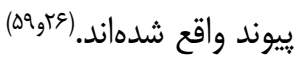
ع- ترميم بافتهاى آسيبديده

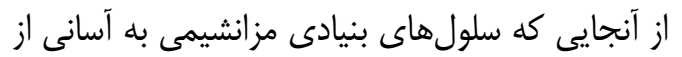

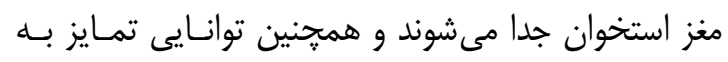

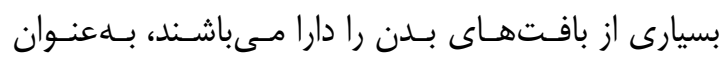

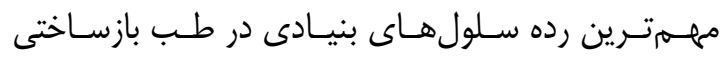
و مهندســــــenerative medicine)

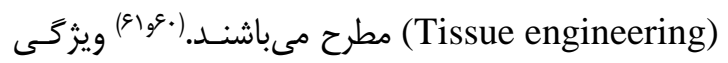

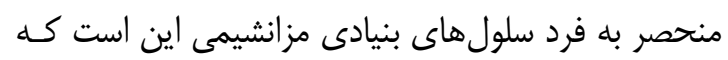

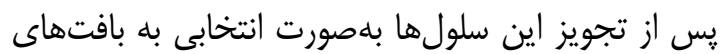

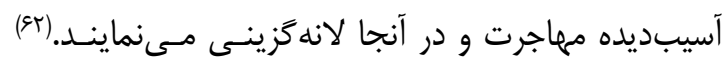

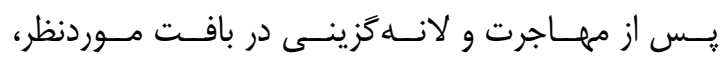

بهلطور كلى يكى از دلايل منطقى استفاده از سلولهاى

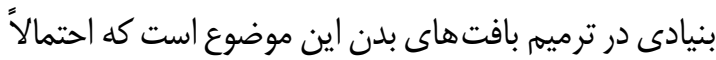

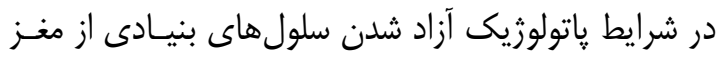
استخوان به داخل خون جهت ترميم بافتهاى آسيبديده

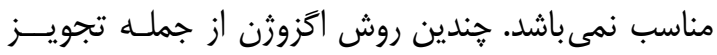

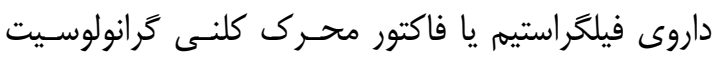
(Granulocyte-Colony Stimulating Factor, G-CSF) باعث افزايش مهـاجرت سـلولهــاى بنيـادى انسدوزن در

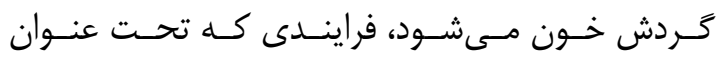
متحركسازى (Mobilization) سلولهاى بنيادى ناميده

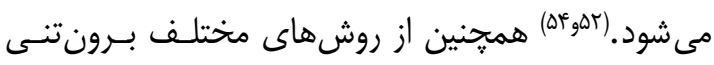

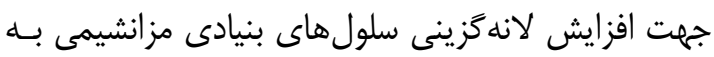

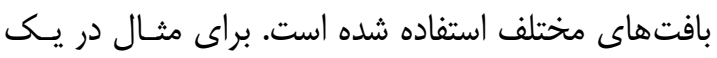
مطالعه مهاجرت و لانهَزينى سلول هاى بنيادى مزانشيمى

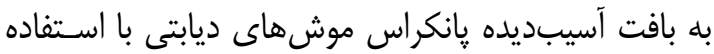

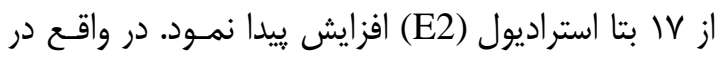

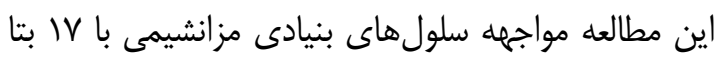

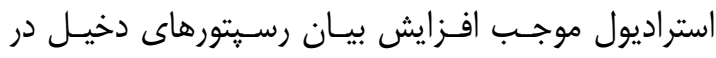
فرايند لانهُّزينى از جمله CXRC4 در سـطح سـلولهـا

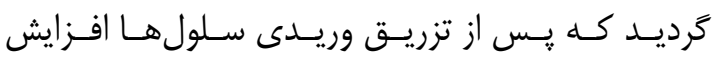

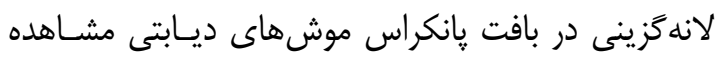

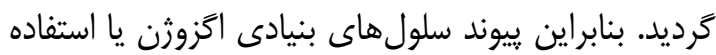

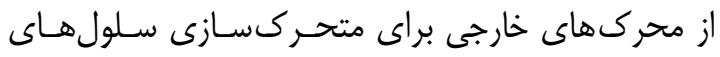

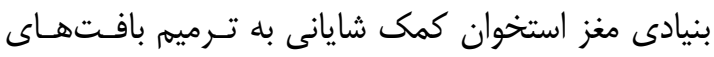

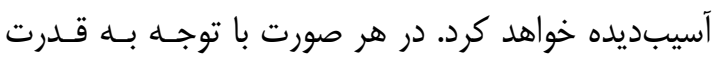

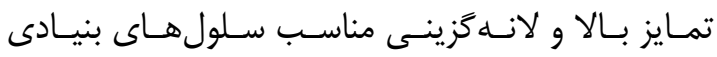

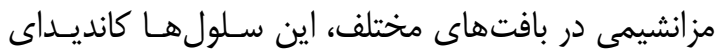

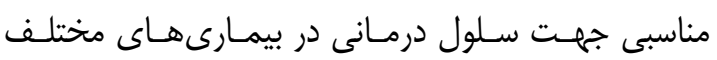

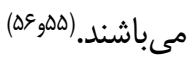

\section{بـ- نقش تعديل كنندَّى ايمنى}

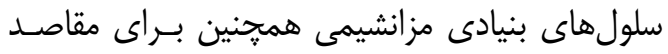

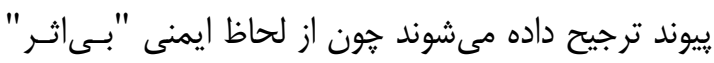

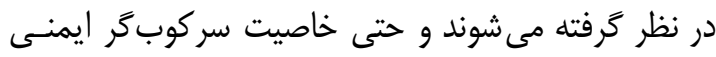
نيز دارند كه آنها را به كانديداهاى ايدهآلى جهت ختص مصارف 
بافت أسيبديده مىشوند. ايسن سـلولهــا داراى عملكـرد

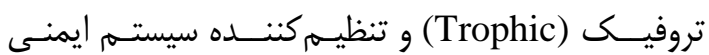

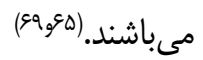
مكانيسـم مولكـولى و شـرايط محيطى كـهـ تمـايز سلولهاى بنيادى مزانشيمى را كنترل مى كند باطور دقيق متيق شناخته نشده است. بسيارى از محققـان يتانسـيل بـالاى فئى

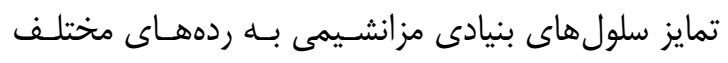

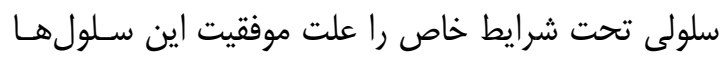

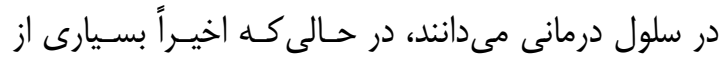
محققان بر اين باورند كه خاصيت ياراكراين (تروفيك) اين داين

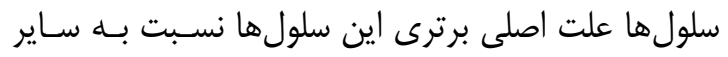

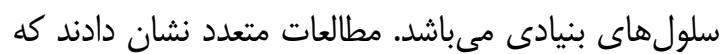
يس از تجويز سلولهاى بنيادى مزانشـيمى فقـط درصــــان

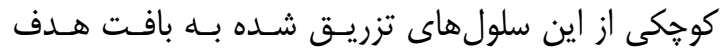

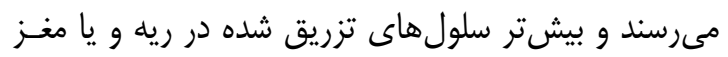

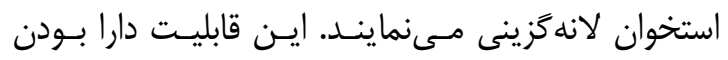

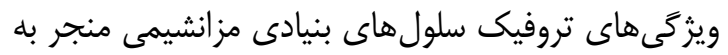
استفاده از تجويز سيستميك اين سلولها بها به جاى تحويـلـيل

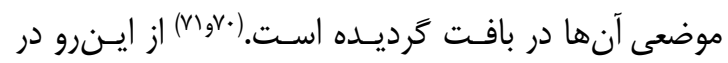

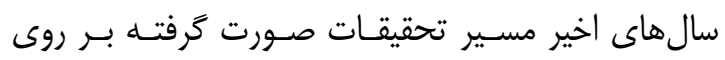
سلولهاى بنيادى مزانشيمى به سمت مكانيسم يـاراكرين تغيير يافت.

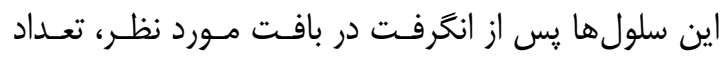

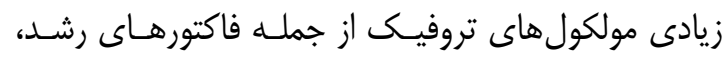
سايتوكينها و فاكتورهاى تنظيمكننده سيستم ايمنس و ... آزاد مى كنند كه نه تنها موجب افزايش لانه كزينى بيشتر

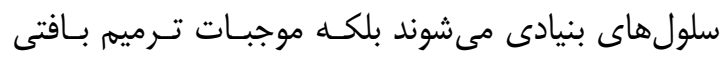

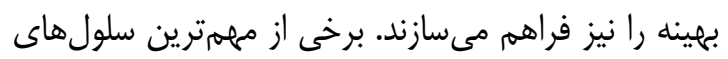
تروفيك شامل سايتوكينهـا (IL10، IL6 IL1،TGFIL8 و ...)، فاكتورهاى ضدآيويتوز، فاكتورهاى تعديل كننده

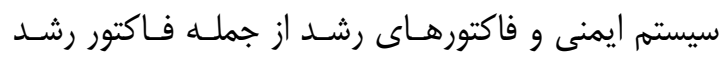

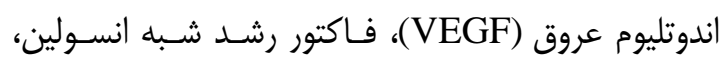
فاكتور رشد هياتوسيت، فاكتور رشد فيبروبلاستى (FGF)،

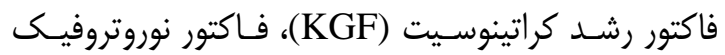

سلولهاى بنيادى مزانشيمى اثرات موضعى خـود را در آن

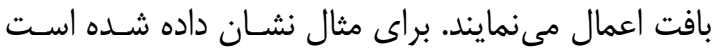

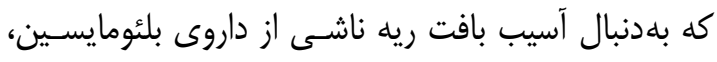

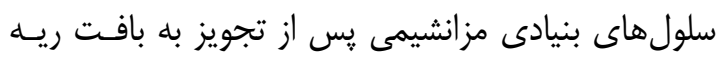

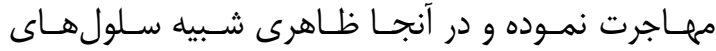

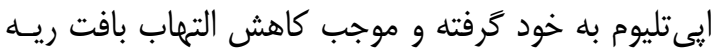

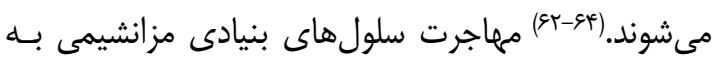

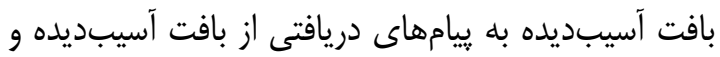

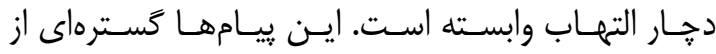

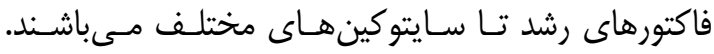

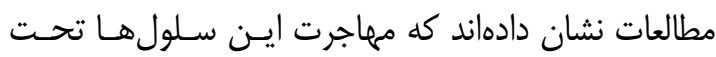

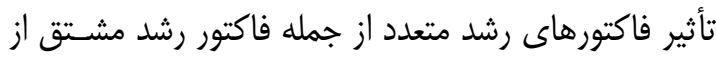
يلاكت (PDFG)، فاكتور رشد شـبه انسـولين (IGF-1)،

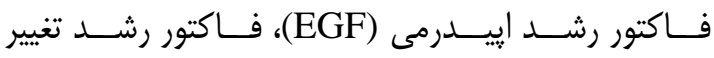

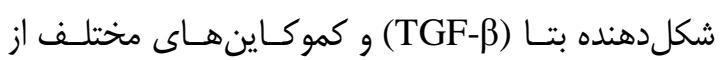
CCR5 , CCR4 ،CR3 CCR2 (CC Chemokine Receptor) براساس مطالعات صورت كرفته و دانش امـروز مشـخص شده هنكامى كه سلولهاى بنيادى مزانشيمى تحت تـأثير

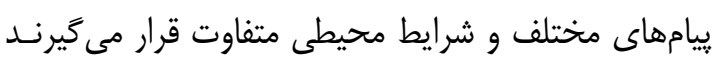
قادر هستند به سه نوع سلول تبديل گردند: 1 - سلولهاى اختصاصى بافت (Tissue-specific cells)

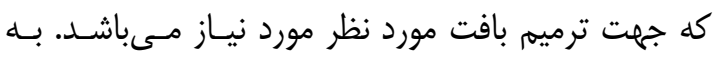

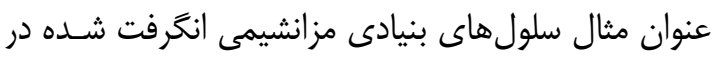
بافت قلب به سلولهاى كارديوميوسيت، سلولهاى عضله

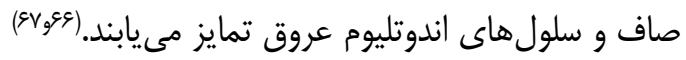
r- سلول هاى عملكردى بافت (Function-relative cells)

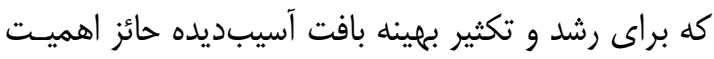

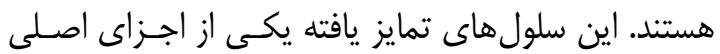
ريز محيط (Microenvironment) مىباشند كـه جهـت افزايش لانهُز ينى و فراينـــــازسـاخت بافـت مـورد نيـاز هستند. (\$1) ب- سلولهاى تنظيمى بافت (Regulatory cells) كه از طريق ترشح سيتوكينهاى مختلف موجب ترميم و احياى 


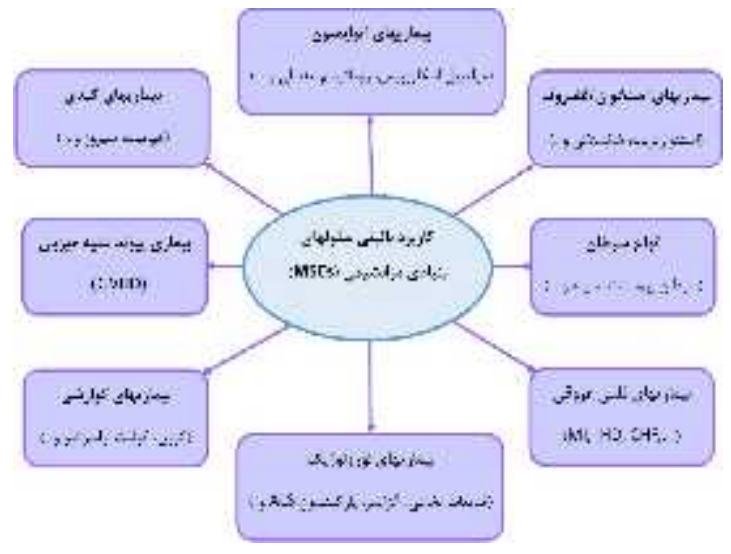

شكل ץ - برخى از مهمترين كاربردهاى بالينى سلولهاى بنيادى مز انشيمى مئر

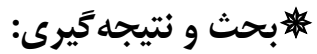

سلولهاى بنيادى، سلولهاى غيرتخصصى درى در بـدن

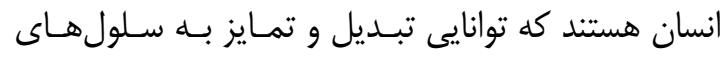

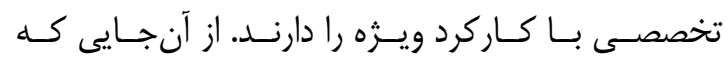

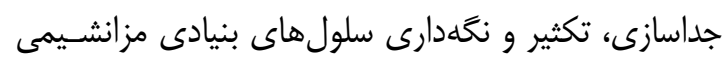
به مراتب راحتتر از ساير سلولهاى بنيادى مىباشد و نيز نيز

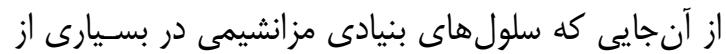

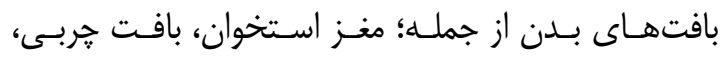

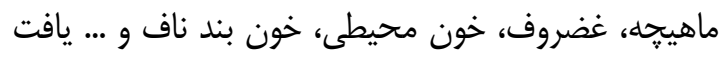

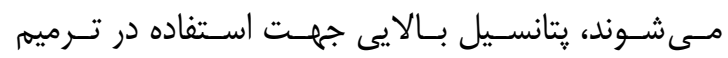

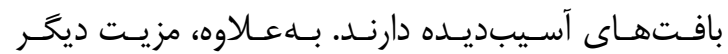

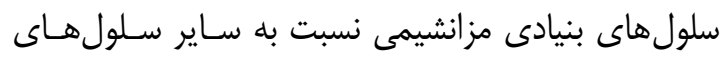

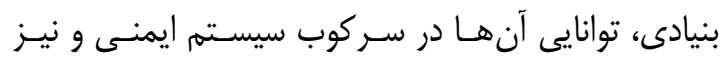

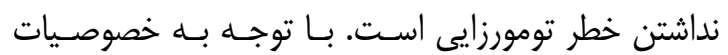
بيولوزيكى اين سلولها و كار آزمـايىهـاى بـالينى متعـداد

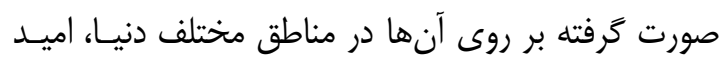

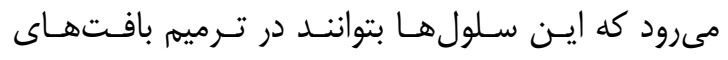
آسيبديده مؤثر واقع شوند. تجربه جِندين سال استـفاده از

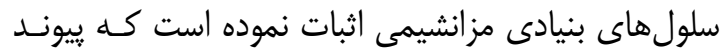
سلولهاى بنيادى مزانشيمى براى انسان بى خطـر بــوده و

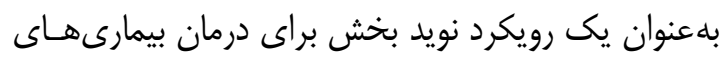
تحليل برنده (Degenerative) و مزمن محسوب مى بـ بردي درد.
مشتق از مغز (BDNF) و ... مىباشــند. مطالعـات نشـان

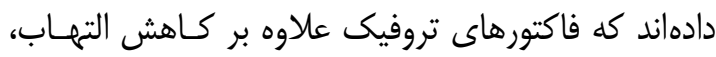

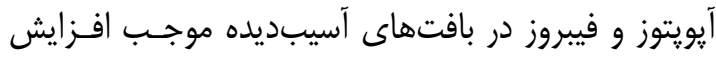

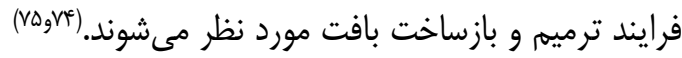

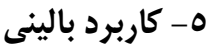

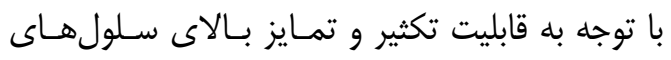

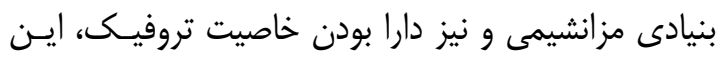

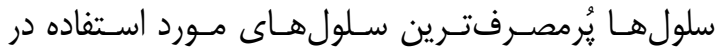

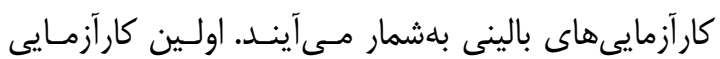

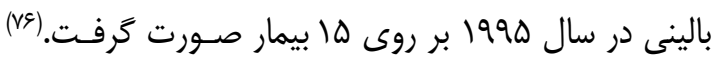

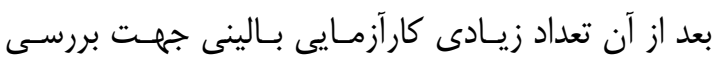
اثربخشى و ايمنى اين سلول ها انجام گرفت. بلهور كلى سلول هاى بنيادى مزانشيمى بـهـعلـت دارا

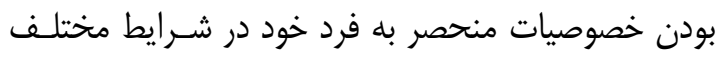

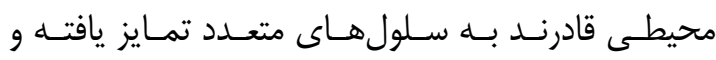

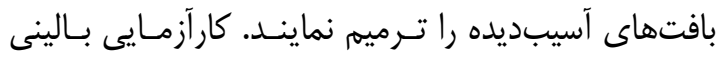

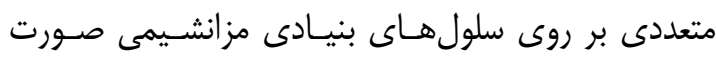

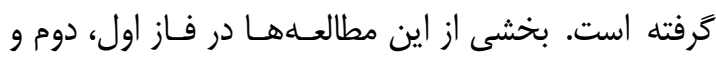

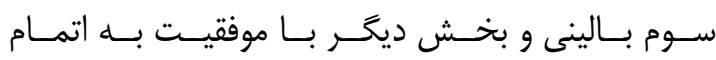

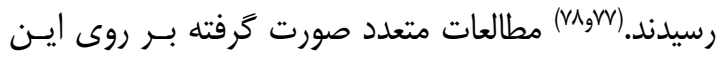

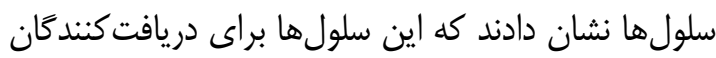

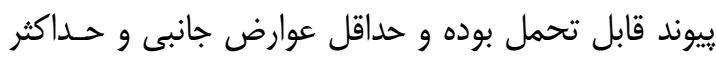

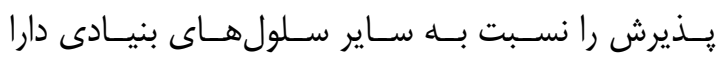

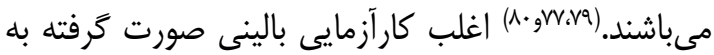
منظور تعيين اثربخشى اين سلولها در درمان بيمارىهاى

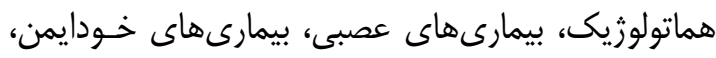

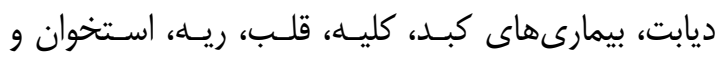

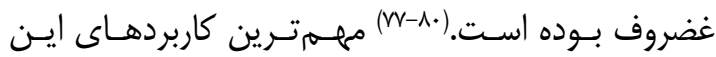
سلولها در درمان بيمارىهاى مختلف در شكل ب خلاصه

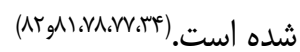


1. Kelly B. Stem cells. Greenwood Publishing Group. 2007: 3-4.

2. Bongso A, Lee EH. Stem cells from bench to bedside: World Scientific Publishing; 2005. 1-13.

3. Parson A. The proteus effect: stem cells and their promise for medicine: Joseph Henry Press; 2004. doi: 10.1172/JCI25763.

4. Potten C. Stem Cells. 1st ed. Academic Press; 1996; 2-11.

5. Lee YK, Cowan CA. Differentiation of white and brown adipocytes from human pluripotent stem cells. Methods Enzymol 2014; 538: 35-47. doi: 10.1016/B978-0-12800280-3.00003-7.

6. Kusuma S, Peijnenburg E, Patel P, Gerecht S. Low Oxygen Tension Enhances Endothelial Fate of Human Pluripotent Stem Cells. Arterioscler Thromb Vasc Biol 2014; 34(4): 913-20. doi: 10.1161/ATVBAHA. 114.303274 .

7. Lindvall O, Kokaia Z, Martinez-Serrano A. Stem cell therapy for human neurodegenerative disorders-how to make it work. Nat Med 2004; 10.S42-50. doi: 10. 1038/nm1064.

8. Bongso A, Mark R. History and perspective of stem cell research. Best Prac \& Res Clin Obstet Gynecol 2004; 18(6): 82742. doi: 10.1016/j.bpobgyn.2004.09. 002.

9. Kalra K, Tomar PC. Stem cell: basics, classification and applications. Am J Phyt Clin Ther 2014; 2(7): 919-30.

10. Ratajczak M, Zuba-Surma E, Wysoczynski M, Wan W, Ratajczak J, Wojakowski W. Hunt for pluripotent stem cell-regenerative medicine search for almighty cell. $\mathrm{J}$ autoimmun 2008 ;

30(3): 151-62. doi: 10.1016/j.jaut.2007.12. 003.

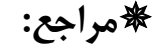

11. Murrell W, Feron F, Wetzig A. Multipotent stem cells from adult olfactory mucosa. Dev Dyn 2005; 233(2): 496-515. doi: 10.1002/dvdy.20360

12. Thomson JA, Itskovitz-Eldor J, Shapiro SS, Waknitz MA, Swiergiel JJ, Marshall VS, et al. Embryonic stem cell lines derived from human blastocysts. Science 1998; 282(5391): 1145-47. doi: 10.1126/science.282.5391. 1145.

13. Dua H, Joseph A, Shanmuganathan V, Jones R. Stem cell differentiation and the effects of deficiency. Eye 2003; 17(8): 87785. doi: 10.1038/sj.eye.6700573.

14. Strauer B, Kornowski R. Stem cell therapy in perspective. Circulation 2003; 107(7): 929-34. doi: 10.1161/01.CIR. 0000057525.13182.24.

15. Blanpain C, Horsley V, Fuchs E. Epithelial stem cells: Turning over new leaves. Cell 2007; 128(3): 445-58. doi: 10. 1016/j.cell.2007.01.014.

16. Bindu H, Srilatha B. Potency of various types of stem cells and their transplantation. $\mathrm{J}$ Stem Cell Res Ther 2011; 1(3): 1-6. doi: 10. 4172/2157-7633.1000115.

17. Priya B. The power of stem cells. Res Rev J Microb Biotech 2015; 4(1): 1-11.

18. Nichols J, Smith A. The origin and identity of embryonic stem cells. Development 2011; 138: 3-8. doi: 10.1242/ dev.050831.

19. Cavaleri F, Schöler HR. Nanog: a new recruit to embryonic stem cell orchestra. Cell 2003 113: 551-2. doi: 10.1016/S0092-8674 (03)00394-5.

20. Kørbling M, Estrove Z. Adult stem cells for tissue repair-a new therapeutic concept? $\mathrm{N}$ Engl J Med 2003 349(6): 570-82. doi: 10. 1056/NEJMra022361. 
21. Zuk P, Zhu M, Ashjian P. Human adipose tissue is a source of multipotent stem cells. Mol Biol Cell Dec 2002 13(12): 4279-95. doi: 10.1091/mbc.E02-02-0105.

22. Fauza DO, Bani M. Fetal stem cells in regenerative medicine: Principles and translational strategies. Springer-Verlag New York, 2016: 9-18.

23. Guillot P, O’Donoghue K, Kurata H, Fisk N. Fetal stem cells: betwixt and between. Semin Reprod 2006; 24: 340-7. doi: 10. 1055/s-2006-952149.

24. O'Donoghue K, Fisk NM. Fetal stem cells. Best Pract Res Clin Obs Gyn 2004; 18(6): 853-75. doi: 10.1016/j.bpobgyn.2004. 06.010 .

25. Qisi S, Zhonge Z, Zhongjie S. The potential and challenges of using stem cells for cardiovascular repair and regeneration. Genes Dis 2014; 1(1): 113-9. doi: 10.1016/j. gendis.2014.07.003.

26. Ryan JM, Barry FP, Murphy JM, Mahon BP. Mesenchymal stem cells avoid allogeneic rejection. J Inflamm (Lond) 2005; 2(8): 1-11. doi: 10.1186/1476-9255-2-8.

27. Deb KD, Sarda K. Human embryonic stem cells: preclinical perspectives. J Transl Med 2008; 6(1): 7. doi: 10.1186/1479-58766-7.

28. Dubie T, Admassu B, Sisay T, Shiferaw H. Basic biology and therapeutic application of stem cells in various human and animal diseases. J Cell Biol Genet 2014; 4: 40-52. doi: 10.5897/JCBG2014.0039.

29. Ray P, De A, Yaghoubi S, Khanna A. Application of adult stem cells in medicine. Stem Cells Int 2015: 258313. doi: 10.1155/ 2015/258313.

30. Posfai E, Tam O, Rossant J. Mechanisms of pluripotency in vivo and in vitro. Curr Top Dev Biol 2014; 107: 1-37. doi: 10.1016/
B978-0-12-416022-4.00001-9.

31. Rong Z, Wang M, Hu Z, Stradner M, Zhu $\mathrm{S}$, Kong $\mathrm{H}$. An effective approach to prevent immune rejection of human ESC-derived allografts. Cell Stem Cell 2014; 14(1): 12130. doi: 10.1016/j.stem.2013.11.014.

32. Howard D, Buttery LD, Shakesheff KM, Roberts SJ. Tissue engineering: strategies, stem cells and scaffolds. J Anat 2008; 213(1): 66-72. doi: 10.1111/j.1469-7580.2008. 00878.x.

33. Garcia-Gareta E, Hua J, Rayan F, Blunn G. Stem cell engineered bone with calciumphosphate coated porous titanium scaffold or silicon hydroxyapatite granules for revision total joint arthroplasty. J Mater Sci Mater Med 2014 25(6): 1553-62. doi: 10.1007/ s10856-014-5170-z.

34. Retrived from: https://clinicaltrials.gov, Accessed April, 2017.

35. Paschos N, Brown W, Eswaramoorthy R, $\mathrm{Hu} \mathrm{J}$, Athanasiou K. Advances in tissue engineering through stem cell-based coculture. J Tissue Eng Regen Med 2015; 9(5): 488-503. doi: 10.1002/term. 1870.

36. Hassan AU, Ghulam H, Zahida R. Role of stem cells in treatment of neurological disorder. Int J Health Sci 2009; 3(2): 227-33.

37. Friedenstein A, Chailakhyan R, Gerasimov U. Bone marrow osteogenic stem cells: in vitro cultivation and transplantation in diffusion chambers. Cell Tissue Kinet 1987 20(3): 263-72. doi: 10.1111/j.1365-2184. 1987.tb01309.x.

38. Caplan AI. Mesenchymal stem cells. J Orthop Res 1991; 9(5): 641-50. doi: 10.1002/ jor.1100090504.

39. Charbord P. Bone marrow mesenchymal stem cells: historical overview and concepts. Hum Gen Ther 2010; 21(9): 1045-56. doi: 10.1089/hum.2010.115. 
40. Bianco P, Robey PG, Simmons PJ. Mesenchymal stem cells: Revisiting history, concepts, and assays. Cell Stem Cell 2008; 2(4): 313-19. doi: 10.1016/j.stem.2008.03. 002 .

41. Owen M, Friedenstein A. Stromal stem cells: marrow-derived osteogenic precursors. Ciba Found Symp 1988; 136: 42-60.

42. Minguell J, Conget P, Erices A. Biology and clinical utilization of mesenchymal progenitor cells. Braz J Med Biol Res 2000; 33(8): 881-7. doi: 10.1590/ S0100879X2000000800003.

43. Sekiya I, Larson B, Smith J, Pochampally R, Cui J, Prockop D. Expansion of human adult stem cells from bone marrow stroma: conditions that maximize the yields of early progenitors and evaluate their quality. Stem cells 2002; 20(6): 530-41. doi: 10.1634/ stemcells.20-6-530.

44. Radtke C, Nino-Fong R, Esparza GB, Stryhn H, McDuffee L. Characterization and osteogenic potential of equine muscle tissueand periosteal tissue-derived mesenchymal stem cells in comparison with bone marrowand adipose tissue-derived mesenchymal stem cells. Am J Vet Res 2013; 74(5): 790-800. doi: 10.2460/ajvr.74.5.790.

45. Aali E, Mirzamohammadi S, Ghaznavi H, Madjd Z, Larijani B, Rayegan S, et al. A comparative study of mesenchymal stem cell transplantation with its paracrine effect on control of hyperglycemia in type 1 diabetic rats. J Diabetes Metab Disord 2014; 13(1): 76. doi: 10.1186/2251-6581-13-76. eCollection 2014.

46. Tang M, Chen W, Liu J, Weir MD, Cheng L, Xu HH. Human induced pluripotent stem cell-derived mesenchymal stem cell seeding on calcium phosphate scaffold for bone regeneration. Tissue Eng Part A 2014;
20(7-8): 1295-305. doi: 10.1089/ten.TEA. 2013.0211. Epub 2014 Jan 7.

47. Zakikhan K, Pournasr B, Vosough M, Nassiri-Asl M. In vitro generated hepatocytelike cells: A novel tool in regenerative medicine and drug discovery. Cell $\mathbf{J}$ (Yakhteh) 2017; 19(2): 204-17. doi: 10. 22074/cellj.2016.4362.

48. Estrada J, Torres Y, Benguría A, Dopazo A, Roche E, Carrera-Quintanar L, et al. Human mesenchymal stem cell-replicative senescence and oxidative stress are closely linked to aneuploidy. Cell Death Dis 2013; 4(6): e691. doi: 10.1038/cddis.2013.211.

49. Butcher EC, Picker LJ. Lymphocyte homing and homeostasis. Science 1996; 272 : 60-6. doi: 10.1126/science.272.5258.60.

50. Kyriakou C, Rabin N, Pizzey A, Nathwani A, Yong K. Factors that influence short-term homing of human bone marrowderived mesenchymal stem cells in a xenogeneic animal model. Haematologica 2008; 93: 1457-65. doi: 10.3324/haematol. 12553. Epub 2008 Aug 25.

51. Sohni A, Verfaillie CM. Mesenchymal stem cells migration homing and tracking. Stem Cells Int 2013: 1-8. doi.org/10.1155/ 2013/130763.

52. Mouiseddine M FS, Semont A, Sache A, Allenet B, Mathieu N. Human mesenchymal stem cells home specifically to radiationinjured tissues in a non-obese diabetes/ severe combined immunodeficiency mouse model. Br J Radiol 2007; 1: 49-55. doi: 10.1259/ bjr/25927054.

53. Becker AD, Riet IV. Homing and migration of mesenchymal stromal cells: How to improve the efficacy of cell therapy? World J Stem Cells 2016; 8(3): 73-7. doi: 10.4252/wjsc.v8.i3.73.

54. Deng J, Zou Z-m, Zhou T-1, Su Y-p, Ai 
G-p, Wang J-p, et al. Bone marrow mesenchymal stem cells can be mobilized into peripheral blood by G-CSF in vivo and integrate into traumatically injured cerebral tissue. Neurol Sci 2011; 32(4): 641-51. doi: 10.1007/s10072-011-0608-2.

55. Toma C, Pittenger M, Cahill K, Byrne B, Kessler P. Human mesenchymal stem cells differentiate to a cardiomyocyte phenotype in the adult murine heart. Circulation 2002; 105(1): 93-8. doi: 10.1161/hc0102.101442

56. Uemura R, Xu M, Ahmad N, Ashraf M. Bone marrow stem cells prevent left ventricular remodeling of ischemic heart through paracrine signaling. Circ Res 2006; 98: 1414-21. doi: 10.1161/01.RES. 0000225952.61196.39.

57. Di Nicola M, Carlo-Stella C, Magni M, Milanesi M, Longoni PD, Matteucci P, et al. Human bone marrow stromal cells suppress $\mathrm{T}$ lymphocyte proliferation induced by cellular or non-specific mitogenic stimuli. Blood 2002; 99(10): 3838-43. doi: 10.1182/blood. V99.10.3838.

58. Kang J, Koo H, Hwang S, Kang S, Ra J, Lee M. Immunomodulatory effects of human amniotic membrane-derived mesenchymal stem cells. J Vet Sci 2012; 13(1): 23-31. doi: 10.4142/jvs.2012.13.1.23.

59. Pittenger M, Mackay A, Beck S, Jaiswal R, Douglas R, Mosca J. Multilineage potential of adult human mesenchymal stem cells. Science 1999; 284(5411): 143-7. doi: 10.1126/science.284.5411.143.

60. Wagner J, Kean T, Young R, Dennis J, Caplan A. Optimizing mesenchymal stem cell-based therapeutics. Curr Opin Biotechnol 2009 20(5): 531-6. doi: 10.1016/j.copbio. 2009.08.009.

61. Li G, Zhang Xa, Wang H, Wang X, Meng $\mathrm{Cl}$, Chan $\mathrm{Cy}$, et al. Comparative proteomic analysis of mesenchymal stem cells derived from human bone marrow, umbilical cord, and placenta: implication in the migration. Proteomics 2009; 9: 20-30. doi: 10.1002/pmic.200701195.

62. Devine SM, Cobbs C, Jennings $M$, Bartholomew A, Hoffman R. Mesenchymal stem cells distr ibute to a wide range of tissues following systemic infusion into nonhuman primates. Blood 2003; 101: 299901. doi: 10.1182/blood-2002-06-1830.

63. Phinney D, Prockop D. Concise review: mesenchymal stem/multipotent stromal cells: the state of transdifferentiation and modes of tissue repair-current views. Stem Cells 2007; 25: 2896-902. doi: 10.1634/stemcells.20070637.

64. Ortiz LA, Gambelli F, McBride C, Gaupp $\mathrm{D}$, Baddoo $\mathrm{M}$, Kaminski $\mathrm{N}$, et al. Mesenchymal stem cell engraftment in lung is enhanced in response to bleomycin exposure and ameliorates its fibrotic effects. Proc Natl Acad Sci USA 2003; 100(14): 8407-11. doi: 10.1073/pnas.1432929100.

65. Kariminekoo S, Movassaghpour A, Rahimzadeh A, Talebi M, Shamsasenjan K, Akbarzadeh A. Implications of mesenchymal stem cells in regenerative medicine. Artif Cell Nanomed Biotechnol 2016; 44(3): 749-57. doi: 10.3109/21691401.2015.1129620.

66. Yagi H S-GA, Parekkadan B. Mesenchymal stem cells: Mechanisms of immunomodulation and homing. Cell Transplant 2010; 19(6): 667-79. doi: 10. 3727/096368910X508762.

67. Spaeth E, Klopp A, Dembinski J. Inflammation and tumor microenvironments: defining the migratory itinerary of mesenchymal stem cells. Gene Ther 2008; 15: 730-8. doi: 10.1038/gt.2008.39.

68. Petrie AC, Tuan R. Therapeutic potential 
of the immunomodulatory activities of adult mesenchymal stem cells. Birth Defects Res C Embryo Today 2010; 90: 67-74. doi: 10. 1002/bdrc. 20174.

69. Ankrum J, Karp JM. Mesenchymal stem cell therapy: two steps forward, one step back. Trends Mol Med 2010; 16: 203-9. doi: 10.1016/j.molmed.2010.02.005.

70. Linero I, Chaparro O. Paracrine effect of mesenchymal stem cells derived from human adipose tissue in bone regeneration. PLOS ONE 2014; 9(9): e107001. doi: 10.1371/ journal.pone.0107001.

71. Liang X, Ding Y, Zhang Y, Tse H, QL. Paracrine mechanisms of mesenchymal stem cell-based therapy: current status and perspectives. Cell Transplant 2014; 23(9): 1045-59. doi: 10.3727/096368913X667709.

72. Kinnaird T, Stabile E, Burnett MS, Shou M, Lee CW, Barr S, et al. Local delivery of marrow-derived stromal cells augments collateral perfusion through paracrine mechanisms. Circulation 2004; 109(12): 1543-49. doi: 10.1161/01.CIR.0000124062. 31102.57 .

73. Spees JL, Lee RH, Gregory CA. Mechanisms of mesenchymal stem/stromal cell function. Stem Cell Res Ther 2016; 7(125). doi: 10.1186/s13287-016-0363-7.

74. Rastegar F SD, Huang J, Zhang W, Zhang BQ, He BC. Mesenchymal stem cells: Molecular characteristics and clinical applications. World J Stem Cells 2010; 2(4): 67-80. doi: 10.4252/wjsc.v2.i4.67.

75. Krampera MG, Glennie S, Dyson J, Scott D, Laylor R, Simpson E, et al. Bone marrow mesenchymal stem cells inhibit the response of naive and memory antigen specific $\mathrm{T}$ cells to their cognate peptide. Blood 2003; 101(9): 3722-9. doi: 10.1182/ blood-2002-07-2104.
76. Lazarus H, Haynesworth S, Gerson S, Rosenthal N, Caplan A. Ex vivo expansion and subsequent infusion of human bone marrow-derived stromal progenitor cells (mesenchymal progenitor cells): implications for therapeutic use. Bone Marrow Transplant 1995; 16(4): 557-64.

77. Wang S, Qu X, Zhao RC. Clinical applications of mesenchymal stem cells. J Hematol Oncol 2012; 5(1): 19. doi: 10.1186/ 1756-8722-5-19.

78. Squillaro T, Peluso G, Galderisi U. Clinical trials with mesenchymal stem cells: an update. Cell Transl 2016; 25(829): 829-48. doi: 10.3727/096368915X689622.

79. Yim H, Jeong H, Cho Y, Jeong S, Oh I. Safety of mesenchymal stem cell therapy: A systematic review and meta-analysis. Cytotherapy 2016; 18(6): S132. doi: 10. 1016/j.jcyt.2016.03.258.

80. Yubo M, Yanyan L, Li L, Tao S, Bo L, Lin C. Clinical efficacy and safety of mesenchymal stem cell transplantation for osteoarthritis treatment: A meta-analysis. PLOS ONE 2017; 12(4): e0175449. doi: 10. 1371/journal.pone.0175449.

81. Barry FP, Murphy JM. Mesenchymal stem cells: clinical applications and biological characterization. Int $\mathrm{J}$ Biochem Cell Biol 2004; 36(4): 568-84. doi: 10.1016/j.biocel. 2003.11.001.

82. Abdallah BM, Kassem M. Human mesenchymal stem cells: from basic biology to clinical application. Gene Ther 2008; 15(2): 109-6. doi: 10.1038/sj.gt.3303067. 